\title{
Comparative study of the effect of water on the heterogeneous reactions of carbonyl sulfide on the surface of $\alpha-\mathrm{Al}_{2} \mathrm{O}_{3}$ and $\mathrm{MgO}$
}

\author{
Y. Liu, Q. Ma, and H. He \\ Research Center for Eco-Environmental Sciences, Chinese Academy of Sciences, Beijing 100085, China \\ Received: 13 January 2009 - Published in Atmos. Chem. Phys. Discuss.: 25 May 2009 \\ Revised: 10 August 2009 - Accepted: 13 August 2009 - Published: 31 August 2009
}

\begin{abstract}
Here we compared the heterogeneous reactions of carbonyl sulfide (OCS) on the surface of $\alpha-\mathrm{Al}_{2} \mathrm{O}_{3}$ and $\mathrm{MgO}$ and the effect of water on the reactions at $300 \mathrm{~K}$ using Knudsen cell - mass spectrometry, diffuse reflectance infrared Fourier transform spectroscopy, and temperature programmed reactions. $\mathrm{H}_{2} \mathrm{~S}$ and $\mathrm{CO}_{2}$ were found to be hydrolysis products of OCS on both $\alpha-\mathrm{Al}_{2} \mathrm{O}_{3}$ and $\mathrm{MgO}$ at ambient temperature. At low water vapor pressure $\left(<6.8 \times 10^{-6}\right.$ Torr), when water vapor pressure in the Knudsen cell reactor increased from $2.3 \times 10^{-6}$ to $6.8 \times 10^{-6}$ Torr, the initial true uptake coefficient of OCS on $\alpha-\mathrm{Al}_{2} \mathrm{O}_{3}$ decreased from $4.70 \pm 0.45 \times 10^{-7}$ to $3.59 \pm 0.34 \times 10^{-7}$; while it increased from $5.19 \pm 0.49 \times 10^{-7}$ to $6.48 \pm 0.62 \times 10^{-7}$ on $\mathrm{MgO}$ under the same conditions. At high relative humidity $(0.07-$ 0.67), the observed uptake coefficients of OCS on $\alpha-\mathrm{Al}_{2} \mathrm{O}_{3}$ and $\mathrm{MgO}$, which were measured using an in situ DRIFTS, decreased from $4.63 \pm 0.22 \times 10^{-6}$ to $1.00 \pm 0.47 \times 10^{-6}$ and from $9.72 \pm 0.46 \times 10^{-5}$ to $7.68 \pm 0.36 \times 10^{-5}$, respectively, when RH increased from 0.07 to 0.67 corresponding to $1.7-$ 15.9 Torr of water vapor pressure. In the $\mathrm{RH}$ region of 0.17-0.67, the average observed uptake coefficient of OCS on $\alpha-\mathrm{Al}_{2} \mathrm{O}_{3}$ and $\mathrm{MgO}$ was equal to $8.34 \pm 2.19 \times 10^{-7}$ and $8.19 \pm 0.48 \times 10^{-5}$, respectively. The restrictive effect of water on the heterogeneous reaction of OCS on the surface of $\alpha-\mathrm{Al}_{2} \mathrm{O}_{3}$ and $\mathrm{MgO}$ was found to be related to competitive adsorption between water and OCS molecules; while the promotive effect of water on the heterogeneous reaction of OCS on the surface of $\mathrm{MgO}$ at low coverage was ascribed to the formation of surface hydroxyl groups. When the environmental RH was greater than the RH of the monolayer,
\end{abstract}

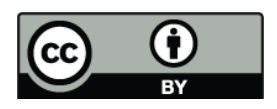

Correspondence to: $\mathrm{H}$. He

(honghe@ rcees.ac.cn) which occurred readily at the atmospherically relevant humidity in the troposphere, thick water layer formed on the mineral dusts, especially, the basic thick water layer formed on the basic component of mineral dusts may be the primary contributor to the heterogeneous hydrolysis of OCS in the troposphere.

\section{Introduction}

Carbonyl sulfide (OCS) is the most abundant sulfur compound in the atmosphere and, in the troposphere, has a rather uniform mixing ratio of approximately $500 \mathrm{pptv}$ (Watts, 2000). The oxidation of OCS in the stratosphere is an important source of stratospheric sulfate aerosol (SSA) during non-volcanic periods (Crutzen, 1976; Engel and Schmidt, 1994; Turco et al., 1980). SSA plays an important role in the Earth's radiation balance (Andreae et al., 1997; Craf, 2004; Turco et al., 1980) and stratospheric ozone chemistry (Solomon et al., 1993). Therefore, much interest has been drawn to the sources and sinks of OCS. In particular, it is important to investigate the tropospheric sinks of OCS because these sinks are not only related to the source of SSA but also to the global chemical cycle of OCS in the atmosphere.

Oxic soils, vegetation, photolysis, and oxidation by $\cdot \mathrm{OH}$ and $\cdot \mathrm{O}$ are the primary sinks of OCS in the atmosphere (Kettle et al., 2002; Montzka et al., 2007; Watts, 2000). In past decades, heterogeneous reactions of trace gases on atmospheric particulate matter (APM) have received much attention. Several atmospheric modeling studies have shown that APM often acts as a sink for certain species (Dentener et al., 1996; Jacob, 2000; Usher, 2003b). Mineral dust, which mainly originates from arid and semi-arid regions having a

Published by Copernicus Publications on behalf of the European Geosciences Union. 
global source strength of $\sim 1000-3000 \mathrm{Tg}$ year $^{-1}$ (Dentener et al., 1996), is one of the most important contributors to the loading of APM. Recently, a few studies demonstrated that heterogeneous reactions of OCS can occur on APM, and on mineral oxides including $\mathrm{Al}_{2} \mathrm{O}_{3}, \mathrm{SiO}_{2}, \mathrm{Fe}_{2} \mathrm{O}_{3}, \mathrm{CaO}, \mathrm{MgO}$, $\mathrm{MnO}_{2}$ and the mixture of $\mathrm{Fe}_{2} \mathrm{O}_{3}$ and $\mathrm{NaCl}$ under ambient conditions (Chen et al., 2007; He et al., 2005; Liu et al., 2006, 2007a, b; Wu et al., 2004, 2005). Although the same intermediate (i.e. hydrogen thiocarbonate, $\mathrm{HSCO}_{2}^{-}$) was observed, the pathways of heterogeneous reactions of OCS still require further study. For example, some researchers have proposed a heterogeneous oxidation mechanism (Chen et al., 2007; He et al., 2005; Liu et al., 2006; Wu et al., 2004, 2005), while recently we found that heterogeneous hydrolysis of OCS can also occur on $\mathrm{MgO}$ (Liu et al., 2007a). Nonetheless, information on the kinetics of the heterogeneous reaction of OCS on mineral oxides is limited. We recently reported uptake coefficients of OCS on $\mathrm{MgO}$ (Liu et al., 2008a), $\alpha-\mathrm{Al}_{2} \mathrm{O}_{3}$ and $\gamma-\mathrm{Al}_{2} \mathrm{O}_{3}$ (Liu et al., 2008b). All of these studies were performed under dry conditions. However, the atmospherically relevant relative humidity $\left(\mathrm{RH}=P / P_{0}\right.$, where $P_{0}$ is the saturated vapor pressure of liquid water) in the troposphere is between 0.20 and 0.90 . The presence of adsorbed water undoubtedly plays a vital role in the heterogeneous reaction of trace gases, such as $\mathrm{HNO}_{3}, \mathrm{O}_{3}$ and $\mathrm{SO}_{2}$ etc., on mineral dust (Al-Abadleh et al., 2005; Roscoe and Abbatt, 2005). Nevertheless, the affect of water on the reaction mechanism and kinetics of OCS on mineral dust remains uncertain.

$\alpha-\mathrm{Al}_{2} \mathrm{O}_{3}$ and $\mathrm{MgO}$ are typical constituents of mineral dust and are widely used as model oxides for the study of trace gas heterogeneous reactions. In this work, diffuse reflectance infrared Fourier transform spectroscopy (DRIFTS), Knudsen cell mass spectrometry (KCMS), and temperatureprogrammed reactions (TPR) were used to investigate the effect of water on the heterogeneous reactions of OCS on $\alpha-\mathrm{Al}_{2} \mathrm{O}_{3}$ and $\mathrm{MgO}$. Our results demonstrate that catalytic hydrolysis of OCS can take place on the surface of both $\alpha$ $\mathrm{Al}_{2} \mathrm{O}_{3}$ and $\mathrm{MgO}$ under ambient conditions and that adsorbed water on mineral dust influences this reaction greatly. The mechanism and the atmospheric implications for the effect of water on the heterogeneous reactions of OCS on mineral oxides are also discussed.

\section{Experimental methods and data evaluation}

\subsection{Materials}

The $\alpha-\mathrm{Al}_{2} \mathrm{O}_{3}$ sample was prepared from boehmite $(\mathrm{AlOOH}$, supplied by Shandong Alumina Corporation) by calcining at $1473 \mathrm{~K}$. The $\mathrm{MgO}$ sample (A. R.) used in this experiment was supplied by the Haizhong Chemical Plant in Tianjin. All other chemicals were used without further purification. These included: Carbonyl sulfide (OCS, $2 \%, \mathrm{OCS} / \mathrm{N}_{2}$, Scott Specialty Gases Inc.), $\mathrm{N}_{2}$ and $\mathrm{O}_{2}$ (99.999\% purity,
Beijing AP BEIFEN Gases Inc.), and $\mathrm{C}_{2} \mathrm{H}_{5} \mathrm{OH}(99.7 \%$, Beijing Chemicals Factory).

\subsection{Characterization of samples}

The X-ray powder diffraction pattern was collected from 10 to $90^{\circ} 2 \theta$ on a D/max-RB automatic powder X-ray diffractometer using $\mathrm{Cu} \mathrm{K} \alpha$ irradiation. The $\mathrm{Al}_{2} \mathrm{O}_{3}$ sample calcined at $1473 \mathrm{~K}$ was identified as $\alpha-\mathrm{Al}_{2} \mathrm{O}_{3}$ with the three main peaks at $35.0^{\circ}, 43.0^{\circ}, 57.0^{\circ}$, and the $\mathrm{MgO}$ sample was identified to be periclase with the three main $2 \theta$ peaks at $42.9^{\circ}$, $62.3^{\circ}$, and $78.6^{\circ}$.

Nitrogen Brunauer-Emmett-Teller (BET) physisorption measurement was performed using a Micromeritics ASAP 2000 automatic instrument. The specific surface area of $\alpha-\mathrm{Al}_{2} \mathrm{O}_{3}$ and $\mathrm{MgO}$ samples was measured to be $12.0 \mathrm{~m}^{2} \mathrm{~g}^{-1}$ and $14.6 \mathrm{~m}^{2} \mathrm{~g}^{-1}$, respectively.

\subsection{Experimental methods}

\subsubsection{KCMS experiments}

A homemade Knudsen cell-mass spectrometer, described in detail elsewhere (Liu et al., 2008a, b), was used to measure the uptake coefficients of OCS at low water vapor pressures in the reactor. Briefly, the particle samples were dispersed evenly on a sample holder with alcohol and then dried at $393 \mathrm{~K}$ for $2 \mathrm{~h}$. The pretreated samples and reactor chamber were evacuated at $323 \mathrm{~K}$ for $6 \mathrm{~h}$ to reach a base pressure of approximately $5.0 \times 10^{-7}$ Torr. The sample cover was closed after the system was cooled to $300 \mathrm{~K}$. OCS (1.51\%) balanced with simulated air $\left(21 \% \mathrm{O}_{2}\right.$ and wet $\left.79 \% \mathrm{~N}_{2}\right)$ in which the water vapor was introduced through a saturated water generator by a $\mathrm{N}_{2}$ stream, was introduced into the reactor chamber through a leak valve. The RH in the feed gas was controlled by the ratio of dry air to wet $\mathrm{N}_{2}$ and was measured using a hygrometer (Center 314) with a relative error of $\pm 1.5 \%$. Prior to the uptake experiments, the system was passivated with the feed gas for 150 min until a steady-state of quadrupole mass spectrometer (QMS) signal of OCS $(\mathrm{m} / \mathrm{z}=60)$ established as the sample was isolated from the gas by the sample cover. Uptake of OCS on all samples was performed with an average OCS partial pressure of $5.3 \pm 0.3 \times 10^{-6}$ Torr, which is equivalent to $1.7 \pm 0.2 \times 10^{11}$ molecules $\mathrm{cm}^{-3}$ or $7.0 \pm 0.3 \mathrm{ppb}$.

For steady-state uptake, the uptake coefficients at different water vapor pressures were calculated using the Knudsen cell equation (Underwood, 2000):

$\gamma_{\mathrm{obs}}=\frac{A_{h}}{A_{g}} \frac{\left(I_{0}-I\right)}{I}$

where $\gamma_{\mathrm{obs}}$ is the observed uptake coefficient, $A_{h}$ is the effective area of the escape aperture $\left(\mathrm{m}^{2}\right), A_{g}$ is the geometric area of the sample holder $\left(\mathrm{m}^{2}\right)$, and $I_{0}$ and $I$ are the mass spectral intensities with the sample holder closed and open, respectively. The effective area of escape aperture, $A_{h}$, was measured according to previously described methodology (Liu 
et al., 2008a, b). As for multilayer powder samples, to consider the contribution of underlying layers of sample to the uptake coefficient, the true uptake coefficient, $\gamma_{t}$, was calculated from:

$\gamma_{t}=$ slope $\cdot\left(\frac{A_{s}}{S_{\mathrm{BET}}}\right)$

where slope is the slope of the plot of $\gamma_{\text {obs }}$ versus the sample mass in the linear region $\left(\mathrm{kg}^{-1}\right), A_{s}$ is the geometric area of the sample holder $\left(\mathrm{m}^{2}\right)$, and $S_{\mathrm{BET}}$ is the specific surface area of the particle sample $\left(\mathrm{m}^{2} \mathrm{~kg}^{-1}\right)$ (Liu et al., 2008a, b; Underwood et al., 2000, 2001). In our previous work, we have measured the linear range for the observed uptake coefficient of OCS on $\alpha-\mathrm{Al}_{2} \mathrm{O}_{3}$ to be $0-70 \mathrm{mg}$ (Liu et al., 2008b), and to be $0-100 \mathrm{mg}$ on $\mathrm{MgO}$ (Liu et al., 2008a). In this study, we kept the sample mass to be $70.0 \mathrm{mg}$ for $\alpha-\mathrm{Al}_{2} \mathrm{O}_{3}$ and $90.0 \mathrm{mg}$ for $\mathrm{MgO}$ to ensure OCS molecules accessing all of the layers of particle samples within the time scale of the KCMS measurement, and BET area of sample was used to calculate $\gamma_{t}$. The relative standard derivation (RSD) for the uptake coefficients was measured to be $9.50 \%$ for repeated experiments. In the Knudsen-cell reactor, all exposed interior surfaces and the surface of the sample holder were coated with Teflon to provide a chemically inert surface. A blank experiment revealed that there was no uptake of OCS by the sample holder under our experiment conditions. Therefore, the wall loss of OCS on the KCMS measurements is negligible.

\subsubsection{TPR experiments}

The instantaneous experiments for the heterogeneous reaction of OCS on mineral oxides were performed with a TPR apparatus. This apparatus consists of a temperatureprogrammed tube oven and a QMS (Hiden HPR20). One quartz tube was used as a sample tube, and another was used as a by-pass tube. The powder samples with 20-40 meshes $(0.5 \mathrm{~g})$ in the sample tube were pretreated in $100 \mathrm{~mL} \mathrm{~min}^{-1}$ of simulated air at $573 \mathrm{~K}$ for $1 \mathrm{~h}$. After the sample cooled to room temperature (r. t.), the two ends of the sample tube were closed, and 1000 ppmv of OCS in simulated air with a total flow rate of $100 \mathrm{~mL} \mathrm{~min}^{-1}$ was introduced into the by-pass tube. The mass channels including $m / z=60(\mathrm{OCS}), 44\left(\mathrm{CO}_{2}\right)$, and $34\left(\mathrm{H}_{2} \mathrm{~S}\right)$ were monitored online with the QMS. Until the steady-state of QMS signal intensity was established, the feed gas was shifted between the sample and by-pass tubes several times. Then, the TPR experiment was performed at $20 \mathrm{~K} \mathrm{~min}^{-1}$ from r. t. to $430 \mathrm{~K}$ as the feed gas passed through the sample tube.

\subsubsection{DRIFTS experiments}

The apparent reaction rate constants at high $\mathrm{RH}$ for the heterogeneous reactions of OCS on $\alpha-\mathrm{Al}_{2} \mathrm{O}_{3}$ and $\mathrm{MgO}$ were measured with a DRIFTS reactor in a closed system. In situ DRIFTS spectra were recorded on a NEXUS 670 (Thermo
Nicolet Instrument Corporation) Fourier transform infrared spectrometer (FTIR) equipped with an in situ diffuse reflection chamber and a high sensitivity mercury cadmium telluride (MCT) detector cooled by liquid $\mathrm{N}_{2}$. The infrared spectra were collected and analyzed by a computer with OMNIC 6.0 software. All spectra reported here were recorded at a resolution of $4 \mathrm{~cm}^{-1}$ for 100 scans. The volume of the reactor chamber in the closed system was $30 \mathrm{~mL}$.

The oxide sample $(\sim 10 \mathrm{mg})$ was finely ground and placed into a ceramic crucible in the in situ chamber. Before the DRIFTS measurement, the sample was pretreated in the in situ chamber at $573 \mathrm{~K}$ in $100 \mathrm{~mL} \mathrm{~min}^{-1}$ of simulated air $\left(79 \% \mathrm{~N}_{2}\right.$ and $\left.21 \% \mathrm{O}_{2}\right)$ for $2 \mathrm{~h}$. After the pretreated sample cooled to $300 \mathrm{~K}$, the reference spectrum was collected. The oxide sample was then exposed to wet air with different RH for $20 \mathrm{~min}$. The RH in the feed gas was controlled and measured as described for the KCMS experiment. After 1000 ppmv of OCS balanced with simulated wet air was introduced into the reactor for $3 \mathrm{~min}$, the inlet and outlet of the reactor chamber were closed promptly. The infrared spectra in the closed system were collected automatically by a computer. The concentration of OCS in the reactor was calibrated with standard OCS gas as described in our previous work (He et al., 2005). From the decrease in concentration of gaseous OCS in the closed system, the apparent quasi first-order reaction rate constants were obtained:

$$
\ln \frac{c_{\mathrm{OCS}, t}}{c_{\mathrm{OCS}, 0}}=k t
$$

where $c_{\mathrm{OCS}, t}$ and $c_{\mathrm{OCS}, 0}$ are the concentrations of OCS at $t \mathrm{~s}$ and $0 \mathrm{~s}$, respectively, $k$ is the apparent reaction rate constant $\left(\mathrm{s}^{-1}\right)$, and $t$ is the reaction time (s). Based on the repeated experiments, the RSD of $k$ was measured to be $4.69 \%$. The observed uptake coefficients were calculated by Eqs. (4) and (5) (Li et al., 2006; Ullerstam et al., 2003):

$\gamma_{\mathrm{obs}}=\frac{k}{Z \cdot A_{s}}$

$Z=\sqrt{\frac{8 R \cdot T}{\pi \cdot M}} \cdot \frac{1}{4 V}$

where $\gamma_{\text {obs }}$ is the observed uptake coefficient, $k$ is the apparent reaction rate constant $\left(\mathrm{s}^{-1}\right), V$ is the reactor chamber volume $\left(\mathrm{m}^{3}\right), Z$ is the collision frequency, $A_{s}$ is the reactive surface area $\left(\mathrm{m}^{2}\right), T$ is the temperature $(\mathrm{K}), R$ is the ideal gas constant $\left(\mathrm{J} \mathrm{mol}^{-1} \mathrm{~K}^{-1}\right)$, and $M$ is the molecular weight of the OCS molecule $\left(\mathrm{kg} \mathrm{mol}^{-1}\right)$.

To investigate the adsorption behavior of water on the model oxides, the infrared spectra and adsorptive isothermal curves of water on oxides were also measured using DRIFTS. Pretreated samples were exposed to wet air with different $\mathrm{RH}$ at $300 \mathrm{~K}$ for $20 \mathrm{~min}$ to establish an adsorption equilibrium. The infrared spectra at equilibrium were collected, and the original spectra were converted using the Kubelka-Munk function (Sirita et al., 2007). The K-M value 

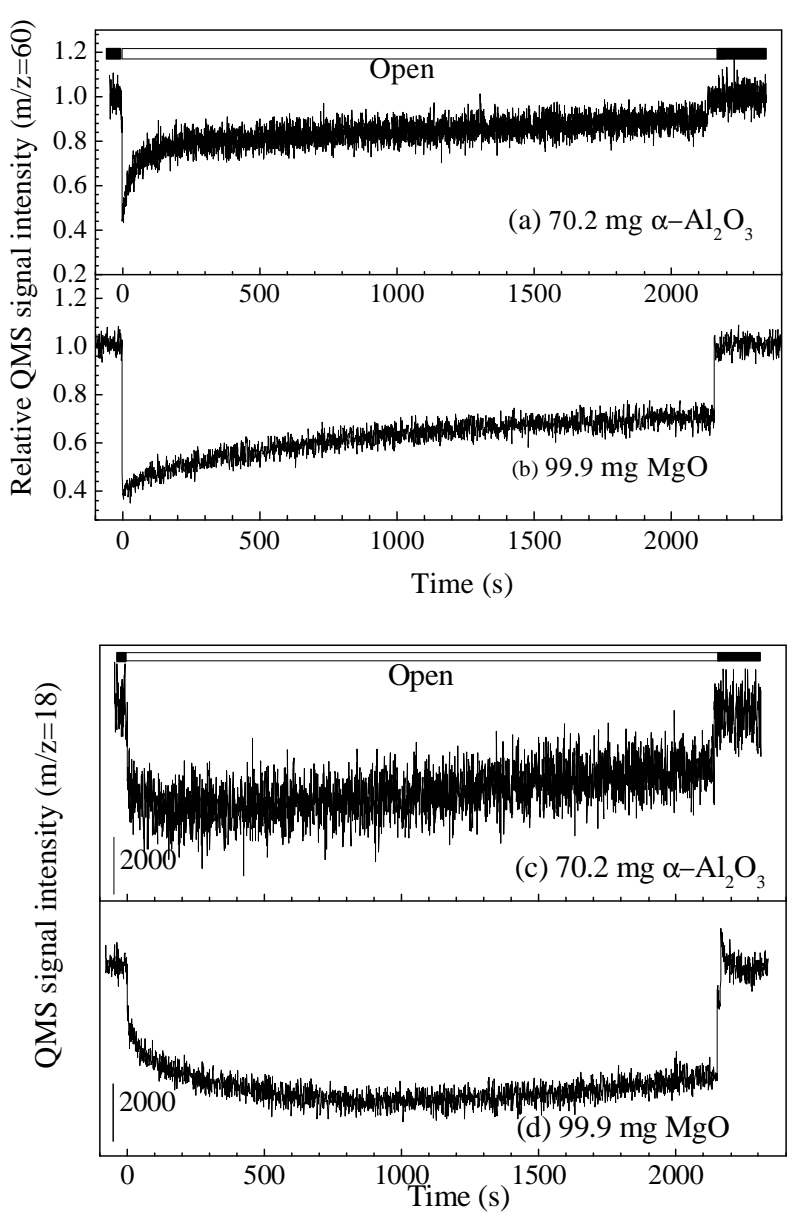

Fig. 1. Typical uptake profiles of OCS and water on $\alpha-\mathrm{Al}_{2} \mathrm{O}_{3}$ and $\mathrm{MgO}$ at $300 \mathrm{~K}$. (a) and (b) for OCS; (c) and (d) for water measured by Knudsen cell - mass spectrometry. The partial pressures of OCS and water in the Knudsen cell reactor were $5.3 \times 10^{-6}$ and $5.8 \times 10^{-6}$ Torr, respectively.

of OH vibrational stretch $\left(3700-2500 \mathrm{~cm}^{-1}\right)$ was used to denote the adsorptive capacity of water on mineral oxides.

\section{Results}

\subsection{Comparative study of the heterogeneous reaction of OCS on the surface of $\alpha-\mathrm{Al}_{2} \mathrm{O}_{3}$ and MgO}

Figure 1 shows typical uptake profiles of OCS and water on $\alpha-\mathrm{Al}_{2} \mathrm{O}_{3}$ and $\mathrm{MgO}$ at $300 \mathrm{~K}$, as measured by KCMS. The partial pressures of OCS and water vapor in the Knudsen cell reactor were $5.3 \times 10^{-6}$ Torr $(7.0 \mathrm{ppb})$ and $5.8 \times 10^{-6}$ Torr, respectively. As shown in Fig. 1a, when the pretreated samples were exposed to the feed gas, the QMS signal intensity of OCS $(\mathrm{m} / \mathrm{z}=60)$ decreased dramatically and was followed by a quick saturation process within $100 \mathrm{~s}$ on $\alpha-\mathrm{Al}_{2} \mathrm{O}_{3}$. An apparent steady-state of uptake on the time scale of this experiment was then quickly reached. However, the QMS signal intensity of OCS $(m / z=60)$ on $\mathrm{MgO}$ came to a steady-state gradually within $1000 \mathrm{~s}$ (Fig. 1b). The quick saturation was ascribed to desorption of adsorbed OCS, while the steady-state uptake was related to the consumption of OCS by the heterogeneous reaction. Therefore, it can be deduced from Fig. 1a and $b$ that desorption of OCS on the surface of $\alpha-\mathrm{Al}_{2} \mathrm{O}_{3}$ was prominent while the heterogeneous reaction was weak. As shown in Fig. 1c and d, the signal intensity of water vapor also decreased when the same sample was exposed to the feed gas. The signal intensity of water vapor on $\alpha-\mathrm{Al}_{2} \mathrm{O}_{3}$ increased gradually with exposure time, while continuous uptake of water was observed on $\mathrm{MgO}$. These results demonstrate that $\alpha-\mathrm{Al}_{2} \mathrm{O}_{3}$ and $\mathrm{MgO}$ can take up OCS and water simultaneously by adsorption and heterogeneous reaction at ambient temperature.

To investigate the surface and gaseous products during the heterogeneous processes of OCS on $\alpha-\mathrm{Al}_{2} \mathrm{O}_{3}$ and $\mathrm{MgO}$, DRIFTS and TPR experiments were performed. As described in Sect. 2.3, the sample was pretreated in the in situ chamber at $573 \mathrm{~K}$ in $100 \mathrm{~mL} \mathrm{~min}^{-1}$ of simulated air $\left(79 \% \mathrm{~N}_{2}\right.$ and $21 \% \mathrm{O}_{2}$ ) for $2 \mathrm{~h}$. The $\mathrm{RH}$ in the feed gas was measured to be 0.07 . Figure 2 shows the surface species formed on $\alpha-\mathrm{Al}_{2} \mathrm{O}_{3}$ and $\mathrm{MgO}$ at $300 \mathrm{~K}$ after $10 \mathrm{~min}$ in the closed system after the pretreated samples were exposed to $1000 \mathrm{ppmv}$ of OCS balanced with air. The cutoffs below $1200 \mathrm{~cm}^{-1}$ in Fig. 2a and $900 \mathrm{~cm}^{-1}$ in Fig. $2 \mathrm{~b}$ were not shown because of the strong lattice vibrational absorption of the samples. The absorption bands shown in Fig. 2 were assigned based on values found in the literature (Table 1). As shown in Fig. 2a, surface hydroxyl $(-\mathrm{OH})$ was consumed and gaseous carbon dioxide $\left(\mathrm{CO}_{2}\right)$, surface carbonic acid $\left(\mathrm{H}_{2} \mathrm{CO}_{3}\right)$, bicarbonate $\left(\mathrm{HCO}_{3}^{-}\right)$, thiocarbonate $\left(\mathrm{HSCO}_{3}^{-}\right)$, carbonate $\left(\mathrm{CO}_{3}^{2-}\right)$ and sulfate $\left(\mathrm{SO}_{4}^{2-}\right)$ were formed on $\alpha-\mathrm{Al}_{2} \mathrm{O}_{3}$. These results are similar to the previously described heterogeneous oxidation of OCS on $\gamma-\mathrm{Al}_{2} \mathrm{O}_{3}$ (He et al., 2005; Liu et al., 2006), suggesting that the heterogeneous oxidation of OCS may also occur on $\alpha-\mathrm{Al}_{2} \mathrm{O}_{3}$. In Fig. $2 \mathrm{~b}$, apart from the above species, sulfur species including physisorbed sulfur dioxide $\left(\mathrm{SO}_{2}\right)$, surface sulfite or bisulfite $\left(\mathrm{SO}_{3}^{2-} / \mathrm{HSO}_{3}^{-}\right)$, and surface hydrogen sulfide $(-\mathrm{SH})$ were also observed. A band at $2578 \mathrm{~cm}^{-1}$ caused by adsorption of surface $-\mathrm{SH}$ was also observed and is shown enlarged in the insert graph in Fig. 2b. The formation of surface - $\mathrm{SH}$ implies that gaseous hydrogen sulfide $\left(\mathrm{H}_{2} \mathrm{~S}\right)$ may be formed during the heterogeneous reaction of OCS on the surface of $\mathrm{MgO}$. However, this hypothesis needs to be further tested. It should be noted that the relative intensity between gaseous $\mathrm{CO}_{2}$ and surface $\mathrm{HCO}_{3}^{-}$in Fig. $2 \mathrm{a}$ is much higher than that in Fig. 2b. This could be due to the fact that the basicity of $\mathrm{MgO}$ is stronger than that of $\alpha-\mathrm{Al}_{2} \mathrm{O}_{3}$, which leads to low gaseous concentrations of $\mathrm{CO}_{2}$ and high surface concentrations of $\mathrm{HCO}_{3}^{-}$. 
Table 1. Assignment of the absorbance bands shown in Fig. 2.

\begin{tabular}{|c|c|c|c|}
\hline Species & Absorbance bands & Oxides & Ref. \\
\hline $\mathrm{OCS}(\mathrm{g})$ & 2071,2052 & $\alpha-\mathrm{Al}_{2} \mathrm{O}_{3}$ and $\mathrm{MgO}$ & Tubergen et al. (2000) \\
\hline $\mathrm{CO}_{2}(\mathrm{~g})$ & 2363,2338 & $\alpha-\mathrm{Al}_{2} \mathrm{O}_{3}$ and $\mathrm{MgO}$ & He et al. (2005) \\
\hline \multirow[t]{2}{*}{$-\mathrm{OH}(\mathrm{a})$} & 3737 & $\alpha-\mathrm{Al}_{2} \mathrm{O}_{3}$ & Peri and Hannan. \\
\hline & 3755 & $\mathrm{MgO}$ & (1960) \\
\hline \multirow[t]{2}{*}{$\mathrm{H}_{2} \mathrm{CO}_{3}$ (a) } & 1683 & $\alpha-\mathrm{Al}_{2} \mathrm{O}_{3}$ & Al-Hosney et al. \\
\hline & 1681 & $\mathrm{MgO}$ & (2004) \\
\hline \multirow{2}{*}{$\mathrm{HCO}_{3}^{-}$(a) } & 3623,1635 & $\alpha-\mathrm{Al}_{2} \mathrm{O}_{3}$ & Lavalley (1996) \\
\hline & $3618,1659,1409,1225$ & $\mathrm{MgO}$ & \\
\hline \multirow{2}{*}{$\mathrm{CO}_{3}^{2-}(\mathrm{a})$} & 1534 & $\alpha-\mathrm{Al}_{2} \mathrm{O}_{3}$ & Baltrusaitis et al. \\
\hline & 1584,1545 & $\mathrm{MgO}$ & $(2006)$ \\
\hline$-\mathrm{SH}(\mathrm{a})$ & 2578 & $\mathrm{MgO}$ & Datta and Cavell (1985) \\
\hline $\mathrm{SO}_{2}(\mathrm{a})$ & 1333 & $\mathrm{MgO}$ & Ullerstam et al. (2003) \\
\hline \multirow[t]{2}{*}{$\mathrm{HSCO}_{2}^{-}(\mathrm{a})$} & 1578 & $\alpha-\mathrm{Al}_{2} \mathrm{O}_{3}$ & He et al. (2005) \\
\hline & 1273 & $\mathrm{MgO}$ & Liu et al. (2007a) \\
\hline \multirow[t]{2}{*}{$\mathrm{SO}_{4}^{2-}(\mathrm{a})$} & 1384 & $\alpha-\mathrm{Al}_{2} \mathrm{O}_{3}$ & Li et al. (2006) \\
\hline & 1138 & $\mathrm{MgO}$ & \\
\hline $\mathrm{SO}_{3}^{2-} / \mathrm{HSO}_{3}^{-}(\mathrm{a})$ & $1084,1030,950$ & $\mathrm{MgO}$ & \\
\hline
\end{tabular}

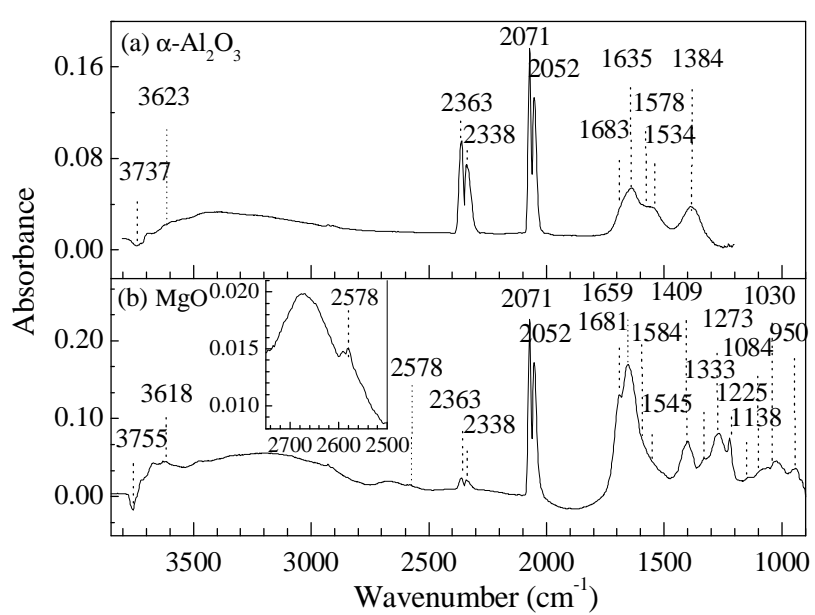

Fig. 2. DRIFTS spetra of the surface species for the heterogeneous reactions of OCS on the surface of $\alpha-\mathrm{Al}_{2} \mathrm{O}_{3}$ and $\mathrm{MgO}$ at $300 \mathrm{~K}$. The spectra were collected at $10 \mathrm{~min}$ in closed system after the samples were exposed to 1000 ppmv of OCS balanced with simulated air.

Figure 3a illustrates the change in QMS signal intensity in the heterogeneous reaction of OCS on $\mathrm{MgO}$ at $300 \mathrm{~K}$. When the MgO sample was exposed to $1000 \mathrm{ppmv}$ of OCS balanced with air, the signal intensity of OCS $(m / z=60)$ decreased initially, and then quickly came to a steady-state due to saturation of adsorption. At the same time, the signal intensities of $\mathrm{CO}_{2}(\mathrm{~m} / \mathrm{z}=44)$ and $\mathrm{H}_{2} \mathrm{~S}(\mathrm{~m} / \mathrm{z}=34)$ increased. When the feed gas was shifted to the by-pass tube (background), the QMS signals of these compounds quickly returned to their corresponding baselines. This indicates that
$\mathrm{H}_{2} \mathrm{~S}$ is also one of the gaseous products of the heterogeneous reaction of OCS on $\mathrm{MgO}$, which supports the spectroscopic results presented in Fig. $2 \mathrm{~b}$ and is also consistent with the results of the Knudsen cell study (Liu et al., 2008a). However, for the heterogeneous reaction of OCS on $\alpha-\mathrm{Al}_{2} \mathrm{O}_{3}$, no changes in the QMS signals of OCS, $\mathrm{CO}_{2}$, or $\mathrm{H}_{2} \mathrm{~S}$ in the flow system were apparent under the same reaction conditions, although the formation of gaseous $\mathrm{CO}_{2}$ and surface $\mathrm{HCO}_{3}^{-}$were easily measured in the closed system (Fig. 2a). These contrary phenomena could be explained by the different ways for data collection. Differential signals were measured by QMS in the flow system; while integrated signal were measured by DRIFTS in the closed system. It should be pointed out that the characteristic absorption band of $-\mathrm{SH}$ was also not observed on $\alpha-\mathrm{Al}_{2} \mathrm{O}_{3}$. These results imply that the reaction of OCS on $\alpha-\mathrm{Al}_{2} \mathrm{O}_{3}$ may differ from that on $\mathrm{MgO}$. It should be noted that the uptake of OCS by $\alpha-\mathrm{Al}_{2} \mathrm{O}_{3}$ at steady-state was much lower than that by $\mathrm{MgO}$ (see Fig. 1), indicating a lower reaction rate. The lack of gaseous $\mathrm{H}_{2} \mathrm{~S}$ or surface $-\mathrm{SH}$ could be ascribed to the low yield of $\mathrm{H}_{2} \mathrm{~S}$ on $\alpha-\mathrm{Al}_{2} \mathrm{O}_{3}$ at r. t., which was lower than the detectable limit of our apparatus. Therefore, TPR experiments were performed to increase the reaction rate and to confirm whether $\mathrm{H}_{2} \mathrm{~S}$ was formed during the heterogeneous reaction of OCS on the surface of $\alpha-\mathrm{Al}_{2} \mathrm{O}_{3}$.

When 1000 ppmv of OCS in air passed through $0.5 \mathrm{~g}$ of $\alpha$ $\mathrm{Al}_{2} \mathrm{O}_{3}$ or $\mathrm{MgO}$ samples and the temperature was increased, the concentration of OCS decreased, and the concentration of $\mathrm{CO}_{2}$ and $\mathrm{H}_{2} \mathrm{~S}$ increased (Fig. $3 \mathrm{c}$ and d). However, the concentration of OCS $(m / z=60), \mathrm{CO}_{2}(m / z=44)$, and $\mathrm{H}_{2} \mathrm{~S}$ $(m / z=34)$ did not change with temperature when the feed gas passed through the by-pass tube. These data suggest that the 

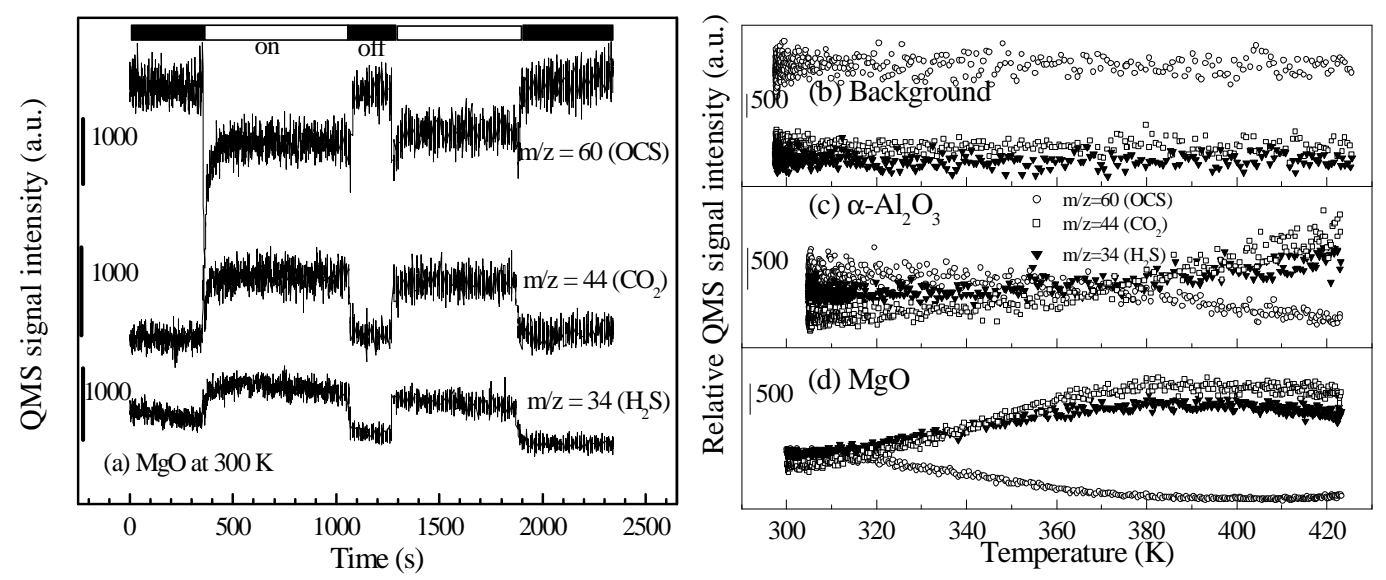

Fig. 3. Gaseous products for the heterogeneous reactions of OCS on the surface of $\alpha-\mathrm{Al}_{2} \mathrm{O}_{3}$ and $\mathrm{MgO}$ measured by temperature programmed reaction. (a) $1000 \mathrm{ppmv}$ of OCS balanced with simulated air passing through $0.5 \mathrm{~g} \mathrm{MgO}$ at $300 \mathrm{~K}$; (b-d) temperature-programmed reaction of 1000 ppmv of OCS balanced with simulated air on back ground, $\alpha-\mathrm{Al}_{2} \mathrm{O}_{3}$ and $\mathrm{MgO}$, respectively. The temperature rate was $20 \mathrm{~K}$ min ${ }^{-1}$.
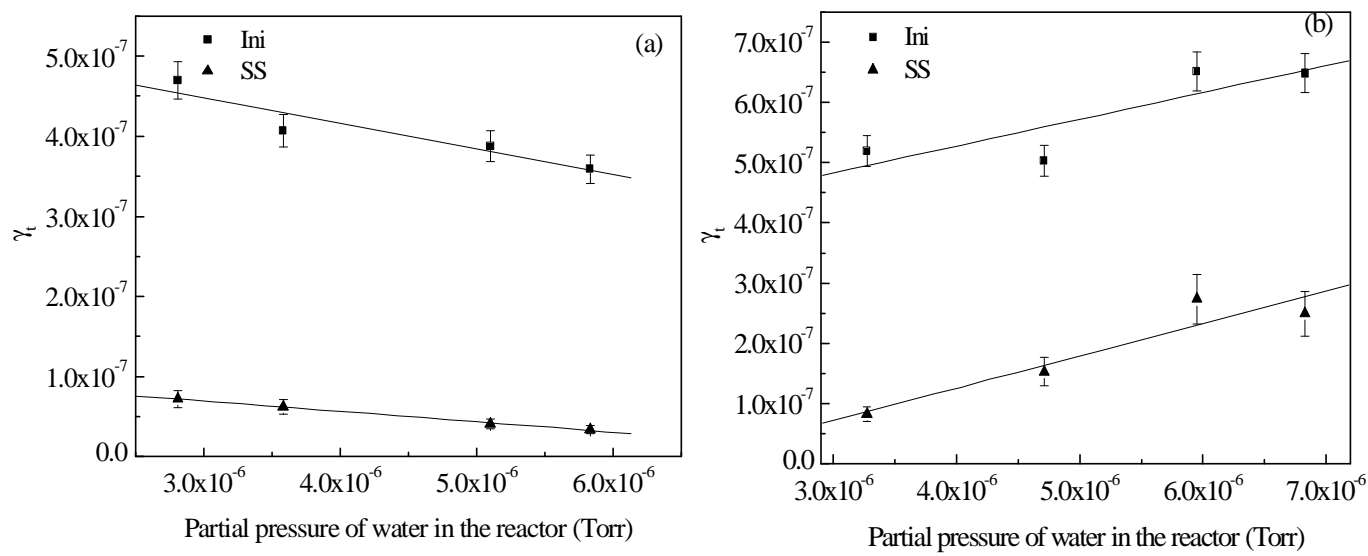

Fig. 4. Effect of water on heterogeneous reactions of OCS at low water vapor pressure. (a) on $\alpha-\mathrm{Al}_{2} \mathrm{O}_{3}$; (b) on $\mathrm{MgO}$ measured by $\mathrm{Knudsen}$ cell - mass spectrometry. The average partial pressure of OCS in the Knudsen cell reactor was kept at $5.3 \pm 0.3 \times 10^{-6}$ Torr, and that of water vapor was $2.5 \times 10^{-6}-6.8 \times 10^{-6}$ Torr. The RSD is $9.50 \%$.

quartz tube did not catalyze the oxidation or hydrolysis of OCS and that OCS did not decompose under our experimental conditions. These results clearly demonstrate that $\mathrm{H}_{2} \mathrm{~S}$ is a gaseous product of the heterogeneous reaction of OCS on $\alpha-\mathrm{Al}_{2} \mathrm{O}_{3}$ and that hydrolysis of OCS also occurs on $\alpha$ $\mathrm{Al}_{2} \mathrm{O}_{3}$. The heterogeneous reaction of OCS on the surface of $\alpha-\mathrm{Al}_{2} \mathrm{O}_{3}$ and $\mathrm{MgO}$ is be described by Reaction (R1).

$\mathrm{OCS}+\mathrm{H}_{2} \mathrm{O} \rightarrow \mathrm{H}_{2} \mathrm{~S}+\mathrm{CO}_{2}$

\subsection{Effect of water on the heterogeneous hydrolysis of OCS on the surface of $\alpha-\mathrm{Al}_{2} \mathrm{O}_{3}$ and $\mathrm{MgO}$}

As shown in Fig. 1, the uptake of water and OCS occurred synchronously when the samples were exposed to the feed gas, followed by hydrolysis reactions of OCS on the surface of $\alpha-\mathrm{Al}_{2} \mathrm{O}_{3}$ and $\mathrm{MgO}$. Because water is one of the reactants, it should have a fundamental effect on the reaction kinetics. Therefore, the reaction kinetics at different water vapor pressures was studied using KCMS and DRIFTS. Figure 4 shows the true uptake coefficient $\left(\gamma_{t}\right)$ of OCS on $\alpha-\mathrm{Al}_{2} \mathrm{O}_{3}$ and $\mathrm{MgO}$ measured by KCMS under different water vapor pressures at $300 \mathrm{~K}$. The partial pressure of water vapor in the Knudsen cell reactor was in the range of $2.5 \times 10^{-6}-6.8 \times 10^{-6}$ Torr. The uptake coefficients under different conditions are shown in Table 2. Chen et al. (2007) measured the $\gamma_{t}$ (BET) OCS on $\mathrm{Fe}_{2} \mathrm{O}_{3}$ to be $1.87 \pm 0.21 \times 10^{-11}$ by DRIFTS with the assumption that OCS accesses all of the layers of particle sample. This value should be the lowest limit and is much lower than our results due to the different samples and different methods. As shown in Fig. 4, the $\gamma_{t}$ of OCS on $\alpha-\mathrm{Al}_{2} \mathrm{O}_{3}$ at 
Table 2. Summary of uptake coefficients of OCS on $\alpha-\mathrm{Al}_{2} \mathrm{O}_{3}$ and $\mathrm{MgO}$.

\begin{tabular}{|c|c|c|c|c|c|c|}
\hline \multirow[b]{2}{*}{ Method } & \multicolumn{3}{|c|}{$\alpha-\mathrm{Al}_{2} \mathrm{O}_{3}$} & \multicolumn{3}{|c|}{$\mathrm{MgO}$} \\
\hline & $\begin{array}{r}P\left(\mathrm{H}_{2} \mathrm{O}\right) \text { (Torr) } \\
\text { or } \mathrm{RH}\end{array}$ & $\gamma_{\text {Ini }}$ & $\gamma_{\mathrm{SS}}$ & $\begin{array}{r}P\left(\mathrm{H}_{2} \mathrm{O}\right) \text { (Torr) } \\
\text { or } \mathrm{RH}\end{array}$ & $\gamma_{\text {Ini }}$ & $\gamma_{\mathrm{SS}}$ \\
\hline \multirow{3}{*}{$\mathrm{KCMS}^{\mathrm{a}}$} & $2.81 \mathrm{E}-6$ & $4.70 \pm 0.45 \mathrm{E}-7$ & $7.20 \pm 0.68 \mathrm{E}-8$ & $3.27 \mathrm{E}-6$ & $5.19 \pm 0.49 \mathrm{E}-7$ & $8.20 \pm 0.78 \mathrm{E}-8$ \\
\hline & $3.58 \mathrm{E}-6$ & $4.07 \pm 0.39 \mathrm{E}-7$ & $6.23 \pm 0.59 \mathrm{E}-8$ & $4.71 \mathrm{E}-6$ & $5.03 \pm 0.68 \mathrm{E}-7$ & $1.53 \pm 0.15 \mathrm{E}-7$ \\
\hline & 5.10 E-6 & $3.88 \pm 0.37 \mathrm{E}-7$ & $4.08 \pm 0.39 \mathrm{E}-8$ & $5.95 \mathrm{E}-6$ & $6.51 \pm 0.62 \mathrm{E}-7$ & $2.73 \pm 0.26 \mathrm{E}-7$ \\
\hline \multirow{7}{*}{ DRIFTS $^{b}$} & 5.83 E-6 & $3.59 \pm 0.34 \mathrm{E}-7$ & $3.35 \pm 0.32 \mathrm{E}-8$ & $6.83 \mathrm{E}-6$ & $6.48 \pm 0.62 \mathrm{E}-7$ & $2.49 \pm 0.24 \mathrm{E}-7$ \\
\hline & 0.07 & \multicolumn{2}{|c|}{$7.38 \pm 0.35 \mathrm{E}-6$} & 0.07 & \multicolumn{2}{|c|}{$9.99 \pm 0.47 \mathrm{E}-5$} \\
\hline & 0.12 & \multicolumn{2}{|c|}{$5.01 \pm 0.23 \mathrm{E}-6$} & 0.12 & \multicolumn{2}{|c|}{$9.04 \pm 0.42 \mathrm{E}-5$} \\
\hline & 0.17 & \multicolumn{2}{|c|}{$3.75 \pm 0.18 \mathrm{E}-6$} & 0.17 & \multicolumn{2}{|c|}{$8.97 \pm 0.42 \mathrm{E}-5$} \\
\hline & 0.22 & \multicolumn{2}{|c|}{$3.29 \pm 0.15 \mathrm{E}-6$} & 0.27 & \multicolumn{2}{|c|}{$8.76 \pm 0.41 \mathrm{E}-5$} \\
\hline & 0.27 & \multicolumn{2}{|c|}{$3.53 \pm 0.17 \mathrm{E}-6$} & 0.47 & \multicolumn{2}{|c|}{$8.17 \pm 0.38 \mathrm{E}-5$} \\
\hline & 0.47 & \multicolumn{2}{|c|}{$3.75 \pm 0.18 \mathrm{E}-6$} & 0.67 & \multicolumn{2}{|c|}{$7.95 \pm 0.37 \mathrm{E}-5$} \\
\hline
\end{tabular}

a BET area of sample was used to measure $\gamma_{t}$ in KCMS experiments.

${ }^{\mathrm{b}}$ Geometric area of sample holder was used to measure $\gamma_{\mathrm{obs}}$.

both the initial (Ini) and steady-states (SS) decreased under conditions of increased water vapor pressure in the Knudsen cell reactor; diametrically opposed effects occurred on $\mathrm{MgO}$. This suggests that water significantly suppressed the adsorption and heterogeneous reaction of OCS on the surface of $\alpha$ $\mathrm{Al}_{2} \mathrm{O}_{3}$ under these experimental conditions. However, water promoted the adsorption and heterogeneous reaction of OCS on the surface of $\mathrm{MgO}$. The linear regression between $\gamma_{t}$ and water vapor pressure $\left(P_{\mathrm{H}_{2} \mathrm{O}}\right)$ can be expressed as follows:

for $\alpha-\mathrm{Al}_{2} \mathrm{O}_{3}$,

$\gamma_{t}($ Ini $)=5.4 \times 10^{-7}-0.032 \times P_{\mathrm{H}_{2} \mathrm{O}}, \quad R=0.937$

$\gamma_{t}(\mathrm{SS})=1.1 \times 10^{-7}-0.013 \times P_{\mathrm{H}_{2} \mathrm{O}}, \quad R=0.999$

for $\mathrm{MgO}$,

$\gamma_{t}($ Ini $)=3.5 \times 10^{-7}+0.044 \times P_{\mathrm{H}_{2} \mathrm{O}}, \quad R=0.858$

$\gamma_{t}(\mathrm{~S} S)=-8.9 \times 10^{-8}+0.054 \times P_{\mathrm{H}_{2} \mathrm{O}}, \quad R=0.939$

In the Knudsen cell reactor, low pressure must be maintained to avoid molecular collisions between gases (Underwood et al., 2000, 2001); the maximal value in our system was $3.5 \times 10^{-4}$ Torr. Even though pure water vapor was introduced into the reactor chamber, the pressure achieved was still much lower than the water vapor pressure found in the atmosphere. Therefore, the effect of water on the heterogeneous reactions of OCS on the surface of $\alpha-\mathrm{Al}_{2} \mathrm{O}_{3}$ and $\mathrm{MgO}$ at relative humidity values representative of the troposphere was investigated using DRIFTS. The initial concentration of OCS in the feed gas was held at 1000 ppmv. The relative humidity in the feed gas was in the range of 0.07-0.67, which corresponds to 1.7-15.9 Torr of water vapor pressure. Figures $5 \mathrm{a}$ and $6 \mathrm{a}$ show the time-dependent logarithmic decline in the concentration of OCS on $\alpha-\mathrm{Al}_{2} \mathrm{O}_{3}$ and $\mathrm{MgO}$ at $300 \mathrm{~K}$ in the closed system. The apparent reaction rate constants were calculated according to Eq. (3); all correlation coefficients were greater than 0.99 . Subsequently, the corresponding $\gamma_{\text {obs }}$ were calculated using Eqs. (4) and (5). As mentioned in 2.3.1, OCS molecules can access the sub-layers for the multi-layer particle samples. However, because the probe depth for OCS molecules in the powder samples could not be obtained in the DRIFTS experiments, the geometric area of the sample holder $\left(0.20 \mathrm{~cm}^{2}\right)$ was used. Thus, the $\gamma_{\text {obs }}$ obtained using this geometric area should be considered as an upper limit. However, the trend between $\gamma_{\text {obs }}$ and RH should be the same as that between $\gamma_{t}$ and RH. The relationship between the $\gamma_{\text {obs }}$ and the RH in the feed gas is shown in Figs. $5 b$ and $6 \mathrm{~b}$.

As shown in Fig. 5b, the $\gamma_{\text {obs }}$ of OCS on $\alpha-\mathrm{Al}_{2} \mathrm{O}_{3}$ decreased sharply with the increase of $\mathrm{RH}$ in the region of $0.07-0.17$. The maximal $\gamma_{\text {obs }}$ was $7.38 \pm 0.35 \times 10^{-6}$ at a $\mathrm{RH}$ of 0.07 . When the RH increased to $0.17, \gamma_{\text {obs }}$ remained at a constant value $\left(3.58 \pm 0.19 \times 10^{-6}\right)$, which was slightly higher than the background value $\left(2.74 \pm 0.13 \times 10^{-6}\right)$ caused by adsorption or reaction on the surface of the reactor chamber. However, as shown in Fig. $6 \mathrm{~b}$, the $\gamma_{\mathrm{obs}}$ of OCS on $\mathrm{MgO}$ decreased slowly from $9.99 \pm 0.47 \times 10^{-5}$ at a $\mathrm{RH}$ of 0.07 to $7.95 \pm 0.37 \times 10^{-5}$ at a RH of 0.67 . The average value of $\gamma_{\text {obs }}$ between the RH values of 0.17 and 0.67 was $8.46 \pm 0.42 \times 10^{-5}$, which was $\sim 30$ times higher than the background value. When the contribution of the background to the uptake coefficients was subtracted, the observed uptake coefficients of OCS on $\alpha-\mathrm{Al}_{2} \mathrm{O}_{3}$ and $\mathrm{MgO}$ decreased from $4.63 \pm 0.22 \times 10^{-6}$ to $1.00 \pm 0.47 \times 10^{-6}$ and from $9.72 \pm 0.46 \times 10^{-5}$ to $7.68 \pm 0.36 \times 10^{-5}$, respectively. The average observed uptake coefficient of OCS on $\alpha-\mathrm{Al}_{2} \mathrm{O}_{3}$ and $\mathrm{MgO}$ was equal to $8.34 \pm 2.19 \times 10^{-7}$ and 

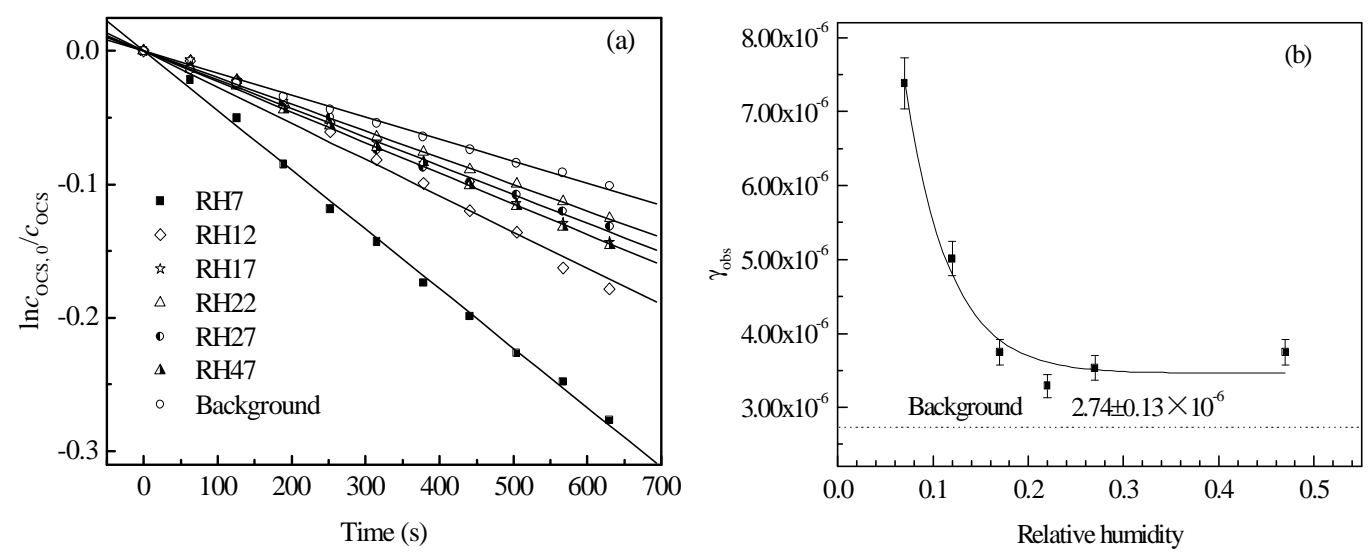

Fig. 5. Effect of water on the heterogeneous reaction of OCS on $\alpha-\mathrm{Al}_{2} \mathrm{O}_{3}$ at high relative humidity calculated from the data of DRIFTS. The initial concentration of OCS in the feed gas was kept at 1000 ppmv. The RSD is $4.69 \%$.
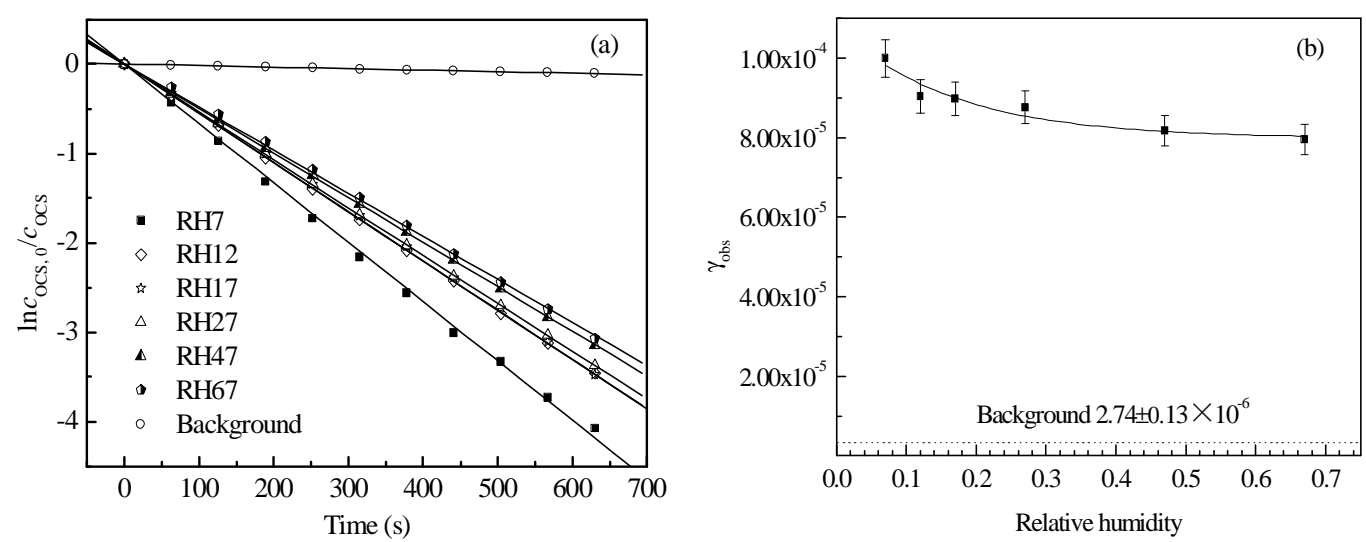

Fig. 6. Effect of water on the heterogeneous reaction of OCS on $\mathrm{MgO}$ at high relative humidity calculated from the data of DRIFTS. The initial concentration of OCS in the feed gas was kept at 1000 ppmv. The RSD is $4.69 \%$.

$8.19 \pm 0.48 \times 10^{-5}$ between the RH values of 0.17 and 0.67 , respectively. It should be noted that the timescale for every spectrum in DRIFTS measurement is $1 \mathrm{~min}$, and the timescale for kinetic parameter evaluation is around $10 \mathrm{~min}$. This value is much longer than that for KCMS measurement. Therefore, the observed uptake coefficient measured with DRIFTS represents the steady state, but not the initial state. On the other hand, it is very hard to compare the data obtained by KCMS and DRIFTS because of the different reaction conditions and different methods. Especially, even though no water was added into the reaction system, the uptake coefficient measured by KCMS was based on the reactive surface area of particle sample, while it was based on the geometric area for DRIFTS. However, it is comparable between $\mathrm{MgO}$ and $\alpha-\mathrm{Al}_{2} \mathrm{O}_{3}$ for the effect of water on the reaction of OCS with the same method and under the same reaction conditions.

\section{Discussion}

\subsection{Catalytic hydrolysis of OCS on the surface of $\alpha-\mathrm{Al}_{2} \mathrm{O}_{3}$ and $\mathrm{MgO}$}

Most studies of OCS reactions in the troposphere have focused on the heterogeneous oxidation of OCS on the surface of alumina etc. (Chen et al., 2007; He et al., 2005; Liu et al., 2006; Wu et al., 2004, 2005), and the hydrolysis pathway has not been elucidated because previous measurements have not measured $\mathrm{H}_{2} \mathrm{~S}$ as a reaction product. In those studies, FTIR was mainly used to investigate the reaction process; however, the sensitivity of infrared absorbance for surface $-\mathrm{SH}$ or gaseous $\mathrm{H}_{2} \mathrm{~S}$ is much lower than that for $\mathrm{CO}_{2}$. In our studies, the slope of the increased signal intensity of $\mathrm{H}_{2} \mathrm{~S}$ with temperature was smaller than that of $\mathrm{CO}_{2}$ (Fig. 3c and $\mathrm{d}$ ). This could be ascribed to the oxidation of gaseous $\mathrm{H}_{2} \mathrm{~S}$ or surface $-\mathrm{SH}$ to other sulfur species with high oxidation states including gaseous $\mathrm{SO}_{2}$, surface $\mathrm{SO}_{3}^{2-} / \mathrm{HSO}_{3}^{-}$and 
$\mathrm{SO}_{4}^{2-}$. These oxidized species were observed in this study (Fig. 2) and in previous works (Chen et al., 2007; He et al., 2005; Liu et al., 2006; Wu et al., 2004, 2005). Therefore, gaseous $\mathrm{CO}_{2}$ is more easily observed than gaseous $\mathrm{H}_{2} \mathrm{~S}$ or surface - SH when using FTIR. In our previous work, we reported the production of $\mathrm{H}_{2} \mathrm{~S}$ for the reaction of OCS on the surface of $\mathrm{MgO}$ using DRIFTS (Liu et al., 2007a) and KCMS (Liu et al., 2008a). Desorption of $\mathrm{H}_{2} \mathrm{~S}$ was also observed after the heterogeneous reaction of OCS on the surface of $\alpha-\mathrm{Al}_{2} \mathrm{O}_{3}$ using KCMS (Liu et al., 2008b). Therefore, we conclude that, similar to reaction on the surface of $\mathrm{MgO}$, heterogeneous hydrolysis of OCS on the surface of $\alpha-\mathrm{Al}_{2} \mathrm{O}_{3}$ also occurs at ambient temperature.

In Fig. 1, the uptake profiles of OCS on $\alpha-\mathrm{Al}_{2} \mathrm{O}_{3}$ and $\mathrm{MgO}$ can be classified into two stages - the quick recover stage and the steady-state stage. Because the uptake experiments were performed under steady-state conditions, the change in OCS intensity can be described according to the conservation of mass by Eq. (10) when the sample was exposed to the reactant gas:

$-\frac{d n_{g}}{d t}=-k^{\prime} d I=k_{\mathrm{ads}} n_{g}(1-\theta)-k_{\mathrm{des}} N_{a}+k_{h} N_{a}$

where $n_{g}$ is the number of gaseous molecules of OCS in the Knudsen cell reactor (molecule), $t$ is time (s), $k^{\prime}$ is a constant, $I$ is the signal intensity of OCS measured by mass spectrometer (a. u.), $k_{\mathrm{ads}}$ is the apparent rate constant for adsorption of OCS $\left(\mathrm{s}^{-1}\right), k_{\text {des }}$ is the apparent rate constant for desorption of OCS $\left(\mathrm{s}^{-1}\right), k_{h}$ is the apparent rate constant for the heterogeneous reaction of OCS $\left(\mathrm{s}^{-1}\right), \theta$ is the coverage of OCS on oxide samples $\left(=N / N_{a}^{*}\right), N_{a}^{*}$ is the saturated coverage of OCS on oxide samples (molecules), and $N_{a}$ is the number of OCS molecule adsorbed on the oxide samples at a given time (molecules).

Therefore, because $\theta$ was almost equal to zero at the initial time, the OCS signal decreased to its lowest intensity when the sample cover was removed. The signal intensity of OCS then gradually recovered because the contribution of desorption became prominent with the increase of $\theta$ (Fig. 1). If there was no catalytic reaction $\left(k_{h}=0\right)$, the OCS signal would eventually recover to baseline due to the balance between adsorption and desorption. However, as shown in Fig. 1, a steady-state consumption of OCS was observed. As discussed above, gaseous and surface products were also detected. Therefore, it can be concluded that the hydrolysis of OCS on the surface of $\alpha-\mathrm{Al}_{2} \mathrm{O}_{3}$ and $\mathrm{MgO}$ is a catalytic reaction. In Fig. 1, the steady-state consumption of OCS on $\mathrm{MgO}$ (Fig. 1b) was much larger than that on $\alpha-\mathrm{Al}_{2} \mathrm{O}_{3}$ (Fig. 1a). The apparent reaction rate constant $\left(k_{h}\right)$ of OCS on $\mathrm{MgO}$ is $0.21 \mathrm{~s}^{-1}$, while $k_{h}$ on $\alpha-\mathrm{Al}_{2} \mathrm{O}_{3}$ is $0.080 \mathrm{~s}^{-1}$. Therefore, compared to $\alpha-\mathrm{Al}_{2} \mathrm{O}_{3}$, the slow recovery rate of the OCS signal on $\mathrm{MgO}$ (Fig. 1b) can be ascribed to the compensatory effect of the catalytic reaction to desorption of OCS. This relationship is well described by Eq. (10).

\subsection{Mechanism for the effect of water on the heterogeneous reactions of OCS on the surface of $\alpha-\mathrm{Al}_{2} \mathrm{O}_{3}$ and $\mathrm{MgO}$}

As shown in Figs. 4a and 5b, adsorbed water on $\alpha-\mathrm{Al}_{2} \mathrm{O}_{3}$ prominently restricted the adsorption and heterogeneous reaction of OCS at low water vapor pressures and at high relative humidity. These data indicate that water and OCS compete for the same adsorption site on $\alpha-\mathrm{Al}_{2} \mathrm{O}_{3}$. On the surface of $\mathrm{MgO}$, adsorbed water promoted the adsorption and heterogeneous reaction of OCS at low water pressures $\left(<6.8 \times 10^{-6}\right.$ Torr) (Fig. 4b), but had the opposite effect at high relative humidity (0.07-0.67) (Fig. 6). Therefore, the effect of water on the heterogeneous reaction or adsorption of OCS on the surface of $\mathrm{MgO}$ appears to utilize different reaction mechanisms under conditions of low water vapor pressures versus high humidity conditions.

In previous work, hydrogen thiocarbonate $\left(\mathrm{HSCO}_{2}^{-}\right)$was determined to be the crucial intermediate for the heterogeneous oxidation and hydrolysis of OCS on mineral oxides; $\mathrm{HSCO}_{2}^{-}$is formed via the reaction of OCS with surface $-\mathrm{OH}$ on mineral oxides (He et al., 2005; Hoggan et al., 1994; Liu et al., 2006, 2007a). Additionally, we found that surface $-\mathrm{OH}$ contributes to not only the formation of $\mathrm{HSCO}_{2}^{-}$ but also to the decomposition of $\mathrm{HSCO}_{2}^{-}$(Liu et al., 2007a). In Fig. 2, the consumption of hydroxyl was also observed. Therefore, the content and properties of surface hydroxyl groups of mineral oxides should be important in these reactions.

On the base of synchrotron-based photoemission spectroscopy, low energy electron diffraction studies and highlevel theoretical simulations, it was found that water molecules could dissociate and react with a low concentration of defective sites on mineral surfaces at very low vapor pressures (Brown Jr., 2001; Eng et al., 2000; Hass et al., 1998; Liu et al., 1998a, b). For example, water molecules react relatively fast with surface defects (corners, edge-step sites, and point defects) on $\mathrm{MgO}$ to form surface $-\mathrm{OH}$ when the water vapor pressure is less than $3 \times 10^{-5}$ Torr. When the water vapor pressure is greater than $10^{-4}$ Torr, dissociative chemisorption of water on terrace sites occurs (Liu et al., $1998 \mathrm{a}, \mathrm{b})$. The formation of surface $-\mathrm{OH}$ at $3700 \mathrm{~cm}^{-1}$ on $\mathrm{MgO}$ at low water coverage was also confirmed using FTIR (Foster et al., 2002). Thus, below $0.05 \mathrm{RH}$, the reaction between water and $\mathrm{MgO}$ can be described by Reaction (R2) (Al-Abadleh et al., 2005):

$\mathrm{MgO}+\mathrm{H}_{2} \mathrm{O} \rightarrow \mathrm{Mg}(\mathrm{OH})_{2}$

In our experiment, the water vapor pressures in the Knudsen cell reactor were lower than $3 \times 10^{-5}$ Torr. The number of surface hydroxyl groups on $\mathrm{MgO}$ would likely increase with water vapor pressure due to the dissociative chemisorption of adsorbed water. As shown in Fig. 4b, adsorbed water promoted the adsorption and heterogeneous reaction of OCS 

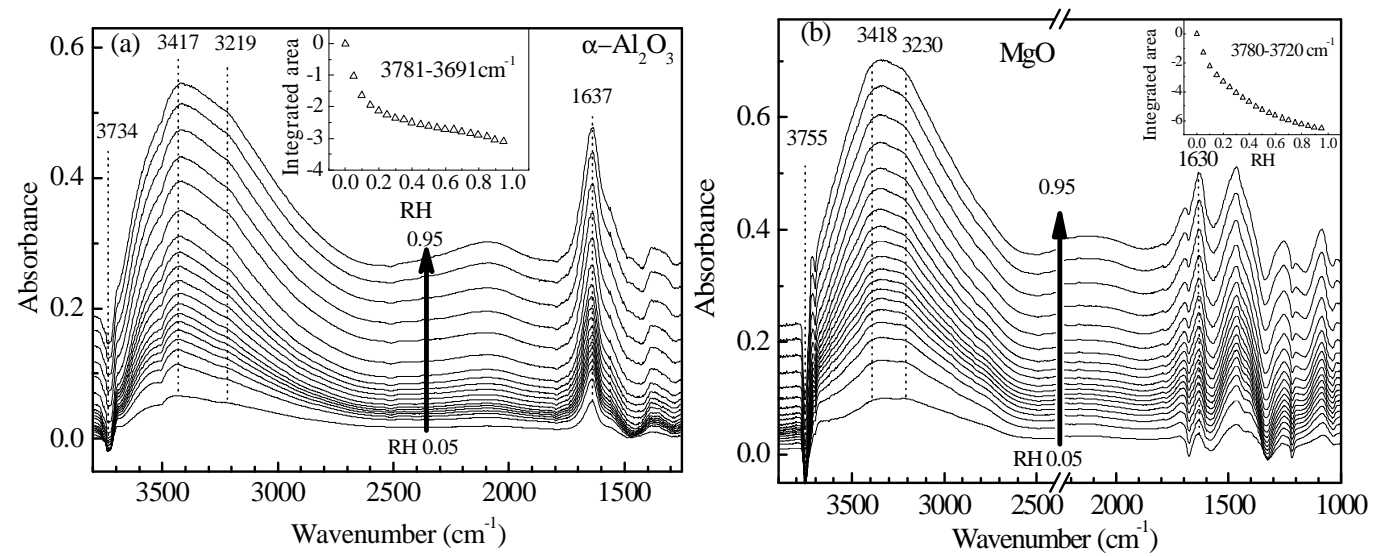

Fig. 7. Adsorption behavior of water at $300 \mathrm{~K}$ on (a) $\alpha-\mathrm{Al}_{2} \mathrm{O}_{3}$ and (b) $\mathrm{MgO}$ measured by DRIFTS.

on the surface of $\mathrm{MgO}$ at low water pressures $\left(<6.8 \times 10^{-6}\right.$ Torr).

As for $\alpha-\mathrm{Al}_{2} \mathrm{O}_{3}$, it was also shown that hydroxylation occurred during the conversion of corundum to gibbsite $\left(\mathrm{Al}(\mathrm{OH})_{3}\right)$ according to Reaction (R3) (Al-Abadleh and Grassian, 2003; Eng et al., 2000; Hass et al., 1998):

$\mathrm{Al}_{2} \mathrm{O}_{3}+3 \mathrm{H}_{2} \mathrm{O} \rightarrow 2 \mathrm{Al}(\mathrm{OH})_{3}$

Although a rather high initial sticking coefficient of 0.1 has been measured for $\mathrm{H}_{2} \mathrm{O}$ on $\alpha-\mathrm{Al}_{2} \mathrm{O}_{3}$ at $300 \mathrm{~K}$, the sticking coefficient was found to decrease exponentially with increasing water coverage (Elam et al., 1998). After the surface is fully hydroxylated, additional water can only be physisorbed on the hydroxyl layer on both $\alpha-\mathrm{Al}_{2} \mathrm{O}_{3}$ and $\mathrm{MgO}$ (Elam et al., 1998; Liu et al., 1998b). Because surface $-\mathrm{OH}$ is the reactive site for the heterogeneous reaction of OCS, the formation of surface $-\mathrm{OH}$ should promote the reaction while the molecular adsorption of water on surface $-\mathrm{OH}$ should suppress this reaction. Theoretically, the uptake coefficients on both $\alpha-\mathrm{Al}_{2} \mathrm{O}_{3}$ and $\mathrm{MgO}$ (shown in Fig. 4) should increase initially and then decrease with the increased water vapor pressures. However, this turning point was not observed, which may be due to limitations of our experiment conditions. It should be pointed out that the $\alpha-\mathrm{Al}_{2} \mathrm{O}_{3}$ sample used in our experiment may have already been partially hydroxylated, which would lead to a turning point that occurs at low water vapor pressures. Therefore, in Figs. $4 \mathrm{a}, 5 \mathrm{~b}$ and $6 \mathrm{~b}$, the decrease in the uptake coefficients of OCS on $\alpha-\mathrm{Al}_{2} \mathrm{O}_{3}$ and $\mathrm{MgO}$ under conditions of increased water vapor pressure can be explained by competitive adsorption of $\mathrm{H}_{2} \mathrm{O}$ and OCS on surface $-\mathrm{OH}$. This assumption is well-supported by the consumption of surface $-\mathrm{OH}$ during the adsorption of pure water vapor on $\alpha-\mathrm{Al}_{2} \mathrm{O}_{3}$ and $\mathrm{MgO}$.

As shown in Fig. 7, when the pretreated samples were exposed to water vapor at different $\mathrm{RH}$, negative bands of surface $-\mathrm{OH}$ at $3734 \mathrm{~cm}^{-1}$ on $\alpha-\mathrm{Al}_{2} \mathrm{O}_{3}$ and $3755 \mathrm{~cm}^{-1}$ on $\mathrm{MgO}$ were observed. The bands at 3417, 3219, and $1637 \mathrm{~cm}^{-1}$ on $\alpha-\mathrm{Al}_{2} \mathrm{O}_{3}$ (as well as 3418,3230 , and $1630 \mathrm{~cm}^{-1}$ on $\left.\mathrm{MgO}\right)$ were assigned to the $v_{a s}(\mathrm{HOH})$, $v_{s}(\mathrm{HOH})$ and $\delta(\mathrm{HOH})$ of adsorbed water, respectively (AlAbadleh et al., 2005). Obviously, the frequencies of the hydroxyl groups consumed by water in Fig. 7 are the same as those consumed by the reaction of OCS in Fig. 2. This suggests that OCS and $\mathrm{H}_{2} \mathrm{O}$ have the same adsorption site on both $\alpha-\mathrm{Al}_{2} \mathrm{O}_{3}$ and $\mathrm{MgO}$.

In Fig. 7, the insert graphs show the variations in the amount of surface $-\mathrm{OH}$ consumed by water at different $\mathrm{RH}$. The consumption of surface $-\mathrm{OH}(A)$ with $\mathrm{RH}$ in Fig. 7 is directionally identical to the corresponding observed uptake coefficient of OCS with RH (Figs. $5 b$ and $6 b$ ). At RH between 0.07 and 0.27 , the observed uptake coefficient of OCS on $\alpha-\mathrm{Al}_{2} \mathrm{O}_{3}$ and $\mathrm{MgO}$ decreased almost linearly with increased consumption of surface hydroxyl $(A)$ by the adsorbed water (shown in Fig. 8). The linear equations are as follows:

$$
\begin{aligned}
\gamma_{\mathrm{obs}} & =8.10 \times 10^{-6}-4.86 \times 10^{-6} \times A, \alpha-\mathrm{Al}_{2} \mathrm{O}_{3}, \\
R & =0.997 ; \\
\gamma_{\mathrm{obs}} & =1.02 \times 10^{-4}-4.76 \times 10^{-6} \times A, \mathrm{MgO}, \\
R & =0.866
\end{aligned}
$$

Although the apparent activity of the heterogeneous reaction of OCS on $\mathrm{MgO}$ is much higher than that on $\alpha-\mathrm{Al}_{2} \mathrm{O}_{3}$, the slope in Eq. (11) is almost equal to that in Eq. (12). This demonstrates that the decrease in $\gamma_{\text {obs }}$ is quantitatively related to the amount of surface hydroxyl groups consumed by adsorbed water regardless of the type of mineral oxide.

It is well known that, depending on the RH value, monolayer and multilayers of water can adsorb to the surface of minerals. To measure the relative humidity of one monolayer $\left(\mathrm{RH}_{\mathrm{ML}}\right)$ of water and to understand the effect of water on the heterogeneous reaction of OCS on the surface of $\alpha-\mathrm{Al}_{2} \mathrm{O}_{3}$ and $\mathrm{MgO}$ at high $\mathrm{RH}$, the adsorption isotherm 
curves of water on these oxides were investigated. The number of adsorbed water layers was assumed to be in direct proportion to the integrated K-M value of the stretch vibration $\left(3700-2500 \mathrm{~cm}^{-1}\right.$ ) of surface adsorbed water (Sirita et al., 2007). Therefore, the coverage of adsorbed water on $\alpha-\mathrm{Al}_{2} \mathrm{O}_{3}$ and $\mathrm{MgO}$ was quantified by generating adsorption isotherm curves according to a three-parameter Type III BET fit, as shown in Eq. (13) (Goodman et al., 2001):

$$
\frac{K M}{K M_{\mathrm{ML}}}=\left(\frac{c \mathrm{RH}}{1-\mathrm{RH}}\right)\left(\frac{1-(n+1) \mathrm{RH}^{n}+n \mathrm{RH}^{n+1}}{1+(c+1) \mathrm{RH}-c \mathrm{RH}^{n+1}}\right)
$$

where $K M$ is the integrated $\mathrm{K}-\mathrm{M}$ value of adsorbed water in the region of $3700-2500 \mathrm{~cm}^{-1}, K M_{\mathrm{ML}}$ is the integrated $\mathrm{K}-\mathrm{M}$ value of adsorbed water at one monolayer, $c$ is a temperaturedependent constant, $n$ is the maximum number of layers of adsorbed water, and RH is the relative humidity. The adsorption isotherm curves of water on $\alpha-\mathrm{Al}_{2} \mathrm{O}_{3}$ and $\mathrm{MgO}$ at $300 \mathrm{~K}$ are shown in Fig. 9.

One monolayer of water adsorbed on $\alpha-\mathrm{Al}_{2} \mathrm{O}_{3}$ and $\mathrm{MgO}$ occurred at a $\mathrm{RH}\left(\mathrm{RH}_{\mathrm{ML}}\right)$ of 0.37 and 0.30 , respectively (Fig. 9). Goodman et al. (2001) measured the $\mathrm{RH}_{\mathrm{ML}}$ of water on $\alpha-\mathrm{Al}_{2} \mathrm{O}_{3}$ and $\mathrm{MgO}$ to be 0.17 and 0.23 , respectively. These values are lower than our results. The difference might be due to the different sample origins. It also should be pointed out that Goodman et al measured the $\mathrm{RH}_{\mathrm{ML}}$ by using a vacuum reactor in which the sample can be cleaned under $10^{-7}$ Torr, while it was performed under ambient pressure in this study. Therefore, the surface cleanliness of the samples may also contribute to this difference. As discussed above, when water vapor pressure exceeds the corresponding $\mathrm{RH}_{\mathrm{ML}}$, multilayer adsorption of water should take place on mineral oxides, and the surface $-\mathrm{OH}$ should be consumed completely. Therefore, uptake of OCS should not be observed at high relative humidity. However, as shown in Figs. $5 b$ and $6 b$, when RH exceeded the corresponding $\mathrm{RH}_{\mathrm{ML}}$, the uptake coefficients of OCS on the samples remained higher than that measured in the background experiment. In particular, the average value of $\gamma_{\mathrm{obs}}$ on $\mathrm{MgO}$ in the RH region between 0.47 and 0.67 was 29 times as that of the background value. This indicates that the thick water layer on $\alpha-\mathrm{Al}_{2} \mathrm{O}_{3}$ and $\mathrm{MgO}$ might also contribute to the heterogeneous hydrolysis of OCS. In our previous work, we found that the heterogeneous reaction of OCS on the surface of mineral oxides is related to the basicity of the oxide (Liu et al., 2007b). The base catalytic hydrolysis of OCS in aqueous solutions has also been widely investigated (Amararene and Bouallou, 2004). It is well known that the basicity of $\mathrm{MgO}$ is higher than that of $\alpha-\mathrm{Al}_{2} \mathrm{O}_{3}$. The $\mathrm{pH}$ value of slurry for $1.0 \mathrm{~g}$ of $\mathrm{MgO}$ in $20.0 \mathrm{~mL}$ water was measured to be 10.7 , while that for $\alpha-\mathrm{Al}_{2} \mathrm{O}_{3}$ was 9.1. Therefore, the observed uptake coefficients of OCS on $\mathrm{MgO}$ at high $\mathrm{RH}(0.07-0.67)$ were much higher than that on $\alpha-\mathrm{Al}_{2} \mathrm{O}_{3}$. At the atmospherically relevant humidity, water could not wet the oxides (Foster et al., 2002). Therefore, the surface basicity of the thick water

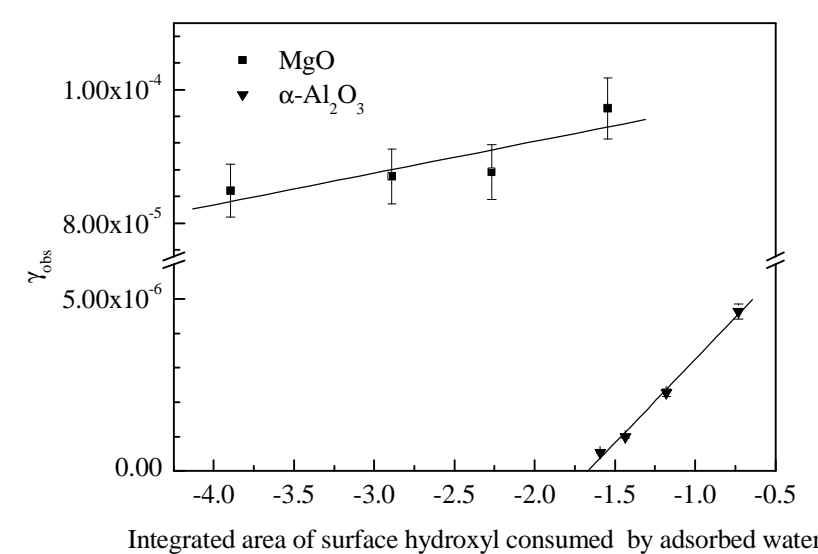

Fig. 8. Correlation between the observed uptake coefficients (measured by DRIFTS) and amount of surface hydroxyl $(A)$ consumed by water at different $\mathrm{RH}$ in the region of $0.07-0.27$. The RSD is $4.69 \%$.

layer formed on mineral dust would be higher than the value measured in slurry. Additionally, it should be noted that not all of the surface $\mathrm{OH}$ sites were consumed by adsorbed water. Instead, as some previous studies (Baltrusaitis et al., 2007) have found that there are adsorbed water islands. That is, water is not adsorbed according to the hypothetical monolayer, but rather in islands such that some surface adsorption sites are still available for reaction by OCS. Consequently, it is reasonable to deduce that both the thick water layer formed on atmospheric particulate matter, especially the basic components and the remained surface hydroxyl groups, should be the main contributors to heterogeneous reactions of OCS in the atmosphere.

\section{Conclusions and atmospheric implications}

In this work, the heterogeneous reactions of OCS on the surface of $\alpha-\mathrm{Al}_{2} \mathrm{O}_{3}$ and $\mathrm{MgO}$ were studied using KCMS, DRIFTS, and TPR. We found that hydrolysis of OCS leading to the formation of $\mathrm{H}_{2} \mathrm{~S}$ and $\mathrm{CO}_{2}$ could occur on the surface of both $\alpha-\mathrm{Al}_{2} \mathrm{O}_{3}$ and $\mathrm{MgO}$ at ambient temperature. The reaction kinetics was influenced significantly by adsorbed water on the surface of $\alpha-\mathrm{Al}_{2} \mathrm{O}_{3}$ and $\mathrm{MgO}$. At low water vapor pressure $\left(<6.8 \times 10^{-6}\right.$ Torr $)$, the uptake coefficients of OCS on $\mathrm{MgO}$ increased with increases in water vapor pressure in the feed gas due to the formation of surface hydroxyl groups; these surface hydroxyl groups were confirmed to be the sites for the heterogeneous reaction of OCS on the surface of mineral oxides. However, at high coverage, adsorbed water on the surface hydroxyl groups led to a decrease in the uptake coefficients on $\mathrm{MgO}$. For $\alpha-\mathrm{Al}_{2} \mathrm{O}_{3}$, adsorbed water suppressed the heterogeneous hydrolysis of OCS at both low and high water vapor pressures due to the competitive adsorption of $\mathrm{H}_{2} \mathrm{O}$ and OCS on surface hydroxyl groups. At 

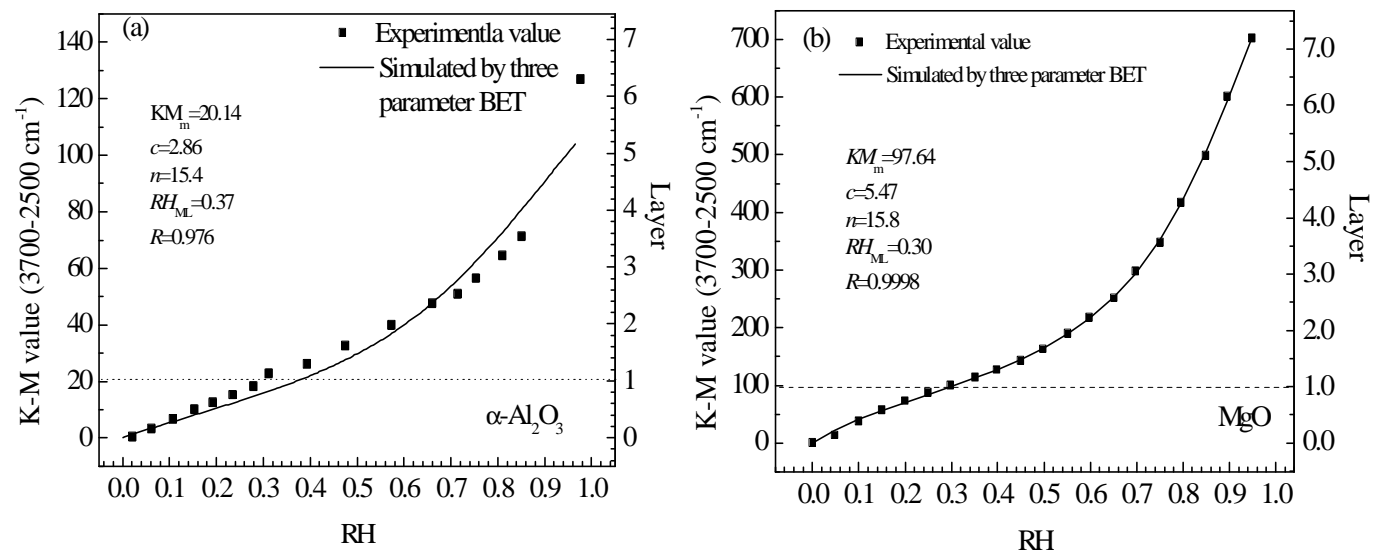

Fig. 9. Adsorptive isothermal curve of water at $300 \mathrm{~K}$ on (a) $\alpha-\mathrm{Al}_{2} \mathrm{O}_{3}$ and (b) $\mathrm{MgO}$ calculated from the data of DRIFTS.

high relative humidity (0.07-0.67), the decrease in the uptake coefficients was in proportion to the amount of surface hydroxyl groups consumed by adsorbed water on $\alpha-\mathrm{Al}_{2} \mathrm{O}_{3}$ and $\mathrm{MgO}$. The uptake coefficients of OCS on $\mathrm{MgO}$ at high relative humidity remained higher than that of both $\alpha-\mathrm{Al}_{2} \mathrm{O}_{3}$ and the background due to the contribution of basic thick water layer of water on $\mathrm{MgO}$.

Hydrolysis is regarded as the most important universal reaction in the atmosphere (Ravishankara, 1997), and much work has been done regarding the hydrolysis of gaseous species on ice surfaces (Abbatt, 2003). Mineral dust has also been found to be an important constituent of atmospheric particulate matter (Dentener et al., 1996). The adsorption and oxidation of inorganic compounds including $\mathrm{SO}_{2}, \mathrm{NOx}$, $\mathrm{O}_{3}$, and $\mathrm{HNO}_{3}$ on the surface of mineral dust have been well investigated (Usher et al., 2003a). However, under typical atmospheric conditions ( $298 \mathrm{~K}$ and $0.50-0.60 \mathrm{RH}$ ), about $3-$ 4 monolayers of water adsorb on mineral dust (Eng et al., 2000). This membrane of liquid formed on the surface of mineral dust imparts particulate matter with a capacity to heterogeneously hydrolyze trace gases. These studies mentioned above demonstrate that heterogeneous oxidation on mineral oxides may be a new sink of OCS in the troposphere. Here we found that mineral dust catalyzes the heterogeneous hydrolysis of OCS, which may be a tropospheric sink for OCS. However, water adsorbed on mineral dust appeared to restrict the heterogeneous hydrolysis of OCS at atmospherically relevant humidity in the troposphere. Nevertheless, the hydrolysis of OCS on mineral dust should not be ignored even if the $\mathrm{RH}$ is higher than $\mathrm{RH}_{\mathrm{ML}}$. Thick water layer of high basicity that formed on mineral dust are likely primary contributors to the heterogeneous hydrolysis of OCS and sinks for OCS in the troposphere. It should be pointed out that in order to gain a good SNR, the concentration of OCS used in this study is higher than that in the troposphere. However, the concentration of OCS in KCMS or DRIFTS measurements was kept as a constant, and only the concen- tration of water (pressure or $\mathrm{RH}$ ) was varied. Therefore, it is still comparable between $\mathrm{MgO}$ and $\alpha-\mathrm{Al}_{2} \mathrm{O}_{3}$ for the effect of water on the reaction of OCS with the same method. The results of this study will help for understanding the chemical cycle of OCS in the troposphere.

Acknowledgements. This research was funded by National Natural Science Foundation of China (40775081), (50621804), the Chinese Academy of Sciences (KZCX2-YW-Q02-03) and the Ministry of Science and Technology, China (2007CB407301).

Edited by: V. F. McNeill

\section{References}

Abbatt, J. P.: Interactions of atmospheric trace gases with ice surfaces: adsorption and reaction, Chem. Rev., 103, 4783-4800, 2003.

Al-Abadleh, H. A., Al-Hosney, H. A., and Grassian, V. H.: Oxide and carbonate surfaces as environmental interfaces: the importance of water in surface composition and surface reactivity, J. Mol. Catal. A-Chem., 228, 47-54, 2005.

Al-Abadleh, H. A. and Grassian, V. H.: FT-IR study of water adsorption on alumina oxide surfaces, Langmuir, 19, 341-347, 2003.

Al-Hosney, H. A. and Grassian, V. H.: Carbonic acid: an important intermediate in the surface chemistry of calcium carbonate, J. Am. Chem. Soc., 126, 8068-8069, 2004.

Amararene, F. and Bouallou, C.: Kinetics of carbonyl sulfide (COS) absorption with aqueous solutions of diethanolamine and methyldiethanolamine, Ind. Eng. Chem. Res., 43, 6136-6141, 2004.

Andreae, M. O. and Crutzen, P. J.: Atmospheric aerosols: biogeochemical sources and role in atmospheric chemistry, Science, 276, 1052-1058, 1997.

Baltrusaitis, J., Jensen, J. H., and Grassian, V. H.: FTIR spectroscopy combined with isotope labeling and quantum chemical calculations to investigate adsorbed bicarbonate formation following reaction of carbon dioxide with surface hydroxyl groups 
on $\mathrm{Fe}_{2} \mathrm{O}_{3}$ and $\mathrm{Al}_{2} \mathrm{O}_{3}$, J. Phys. Chem. B, 110, 12005-12016, 2006.

Baltrusaitis, J., Schuttlefield, J., Jensen, J. H., and Grassian, V. H.: FTIR spectroscopy combined with quantum chemical calculations to investigate adsorbed nitrate on aluminum oxide surfaces in the presence and absence of co-adsorbed water, Phys. Chem. Chem. Phys., 9, 4970-4980, 2007.

Brown Jr., G. E.: How minerals react with water, Science, 294, 6770, 2001.

Chen, H. H., Kong, L. D., Chen, J. M., Zhang, R. Y., and Wang, L.: Heterogeneous uptake of carbonyl sulifide on hematite and hematite- $\mathrm{NaCl}$ mixtures. Environ. Sci. Technol., 41, 6484-6490, 2007

Craf, H. F.: The complex interaction of aerosols and clouds, Science, 303, 1309-1311, 2004.

Crutzen, P. J.: The possible importance of CSO for the sulfate layer of the stratosphere, Geophys. Res. Lett., 3, 73-76, 1976.

Datta, A. and Cavell, R. G.: Claus catalysis, 2, An FTIR study of the adsorption of $\mathrm{H}_{2} \mathrm{~S}$ on the alumina catalyst, J. Phys. Chem., 89, 450-454, 1985.

Dentener, F. J., Carmichael, G. R., Zhang, Y., Lelieveld, J., and Crutzen, P. J.: Role of mineral aerosol as a reactive surface in the global troposphere, J. Geophys. Res., 101, 22869-22889, 1996.

Elam, J. W., Nelson, C. E., Cameron, M. A., Tolbert, M. A., and George, S. M.: Adsorption of $\mathrm{H}_{2} \mathrm{O}$ on a single-crystal $\alpha-\mathrm{Al}_{2} \mathrm{O}_{3}$ (0001) surface, J. Phys. Chem. B, 102, 7008-7015, 1998.

Eng, P. J., Trainor, T. P., Brown Jr., G. E., Waychunas, G. A., Newville, M., Sutton, S. R., and Rivers, M. L.: Structure of the hydrated $\alpha-\mathrm{Al}_{2} \mathrm{O}_{3}$ (0001) surface, Science, 288, 1029-1033, 2000.

Engel, A. and Schmidt, U.: Vertical profile measurements of carbonyl sulfide in the stratosphere, Geophys. Res. Lett., 22(20), 2219-2222, 1994.

Foster, M., Furse, M., and Passno, D.: An FTIR study of water thin films on magnesium oxide, Surf. Sci., 502/503, 102-108, 2002.

Goodman, A. L., Bernard, E. T., and Grassian, V. H.: Spectroscopic study of nitric acid and water adsorption on Oxide particles: enhanced nitric acid uptake kinetics in the presence of adsorbed water, J. Phys. Chem. A, 105, 6443-6457, 2001.

Hass, K. C., Schneider, W. F., Curioni, A., and Andreoni, W.: The chemistry of water on alumina surfaces: reaction dynamics from first principles, Science, 282, 265-268, 1998.

He, H., Liu, J. F., Mu, Y. J., Yu, Y. B., and Chen, M. X.: Heterogeneous oxidation of carbonyl sulfide on atmospheric particles and alumina, Environ. Sci. Technol., 39, 9637-9642, 2005.

Hoggan, P. E., Aboulayt, A., Pieplu, A., and Lavalley, J. C.: Mechanism of COS hydrolysis on alumina, J. Catal., 149, 300-306, 1994

Jacob, D. J.: Heterogeneous chemistry and tropospheric ozone, Atmos. Environ., 34, 2131-2159, 2000.

Kettle, A. J., Kuhn, U., von Hobe, M., Kesselmeier, J., and Andreae, M. O.: Global budget of atmospheric carbonyl sulfide: temporal and spatial variations of the dominant sources and sinks, J. Geophys. Res., 107(D22), 4658, doi:10.1029/2002JD002187, 2002.

Lavalley, J. C.: Infrared spectrometric studies of the surface basicity of metal oxides and zeolites using adsorbed probe molecules, Catal. Today, 27, 377-401, 1996.

Li, L., Chen, Z. M., Zhang, Y. H., Zhu, T., Li, J. L., and Ding, J.: Kinetics and mechanism of heterogeneous oxidation of sulfur dioxide by ozone on surface of calcium carbonate, Atmos. Chem. Phys., 6, 2453-2464, 2006,

http://www.atmos-chem-phys.net/6/2453/2006/.

Liu, J. F., Yu, Y. B., Mu, Y. J., and He, H.: Mechanism of heterogeneous oxidation of carbonyl sulfide on $\mathrm{Al}_{2} \mathrm{O}_{3}$ : an in situ diffuse reflectance infrared Fourier transform spectroscopy investigation, J. Phys. Chem. B, 110, 3225-3230, 2006.

Liu, P., Kendelewicz, T., and Brown Jr., G. E.: Reaction of water with $\mathrm{MgO}$ (100) surfaces, Part II: synchrotron photoemission studies of defective surfaces, Surf. Sci., 412/413, 315-332, 1998a.

Liu, P., Kendelewicz, T., Brown Jr., G. E., and Parks, G. A.: Reaction of water with $\mathrm{MgO}$ (100) surfaces, Part I: synchrotron $\mathrm{X}$-ray photoemission studies of low-defect surfaces, Surf. Sci., 412/413, 287-314, 1998b.

Liu, Y. C., He, H., and Ma, Q. X.: Temperature dependence of the heterogeneous reaction of carbonyl sulfide on magnesium oxide, J. Phys. Chem. A, 112, 2820-2826, 2008a.

Liu, Y. C., He, H., and Mu, Y. J.: Heterogeneous reactivity of carbonyl sulfide on $\alpha-\mathrm{Al}_{2} \mathrm{O}_{3}$ and $\gamma-\mathrm{Al}_{2} \mathrm{O}_{3}$, Atmos. Environ., 42, 960-968, 2008b.

Liu, Y. C., He, H., Xu, W. Q., and Yu, Y. B.: Mechanism of heterogeneous reaction of carbonyl sulfide on magnesium oxide, $\mathrm{J}$ Phys. Chem. A, 111, 4333-4339, 2007a.

Liu, Y. C., Liu, J. F., He, H., Yu, Y. B., and Xue, L.: Heterogeneous oxidation of carbonyl sulfide on mineral oxides, Chinese Sci. Bull., 52, 2063-2071, 2007b.

Montzka, S. A., Calvert, P., Hall, B. D., Elkins, J. W., Conway, T. J., Tans, P. P., and Sweeney, C.: On the global distribution, seasonality, and budget of atmospheric carbonyl sulfide (COS) and some similarities to $\mathrm{CO}_{2}$, J. Geophys. Res., 112, D09302, doi:10.1029/2006JD007665, 2007.

Peri, J. B. and Hannan, R. B.: Surface hydroxyl groups on $\gamma$ alumina, J. Phys. Chem., 64, 1526-1530, 1960.

Ravishankara, A. R.: Heterogeneous and multiphase chemistry in the troposphere, Scinece, 276, 1058-1065, 1997.

Roscoe, J. M. and Abbatt, J. P. D.: Diffuse reflectance FTIR study of the interaction of alumina surfaces with ozone and water Vapor, J. Phys. Chem. A, 109, 9028-9034, 2005.

Sirita, J., Phanichphant, S., and Meunier, F. C.: Quantitative analysis of adsorbate concentrations by diffuse reflectance FT-IR, Anal. Chem., 79, 3912-3918, 2007.

Solomon, S., Sanders, R. W., Garcia, R. R., and Keys, J. G.: Increased chlorine dioxide over Antarctica caused by volcanic aerosols form Mount Pinatubo, Nature, 363, 245-248, 1993.

Tubergen, M. J., Lavrich, R. J., and McCargar, J. W.: Infrared spectrum and group theoretical analysis of the vibrational modes of carbonyl sulfide, J. Chem. Educ., 77(12), 1637-1639, 2000.

Turco, R. P., Whitten, R. C., Toon, O. B., Pollack, J. B., and Hamill, P.: OCS, stratospheric aerosols and climate, Nature, 283, 283286, 1980.

Ullerstam, M., Johnson, M. S., Vogt, R., and Ljungström, E. DRIFTS and Knudsen cell study of the heterogeneous reactivity of $\mathrm{SO}_{2}$ and $\mathrm{NO}_{2}$ on mineral dust, Atmos. Chem. Phys., 3, 2043 2051, 2003, http://www.atmos-chem-phys.net/3/2043/2003/.

Underwood, G. M., Li, P., Al-Abadleh, H. A., and Grassian, V. H.: A Knudsen cell study of the heterogeneous reactivity of nitric acid on oxide and mineral dust particles, J. Phys. Chem. A, 105, 
6609-6620, 2001.

Underwood, G. M., Li, P., Usher, C. R., and Grassian, V. H.: Determining accurate kinetic parameters of potentially important heterogeneous atmospheric reactions on solid particle surfaces with a Knudsen cell reactor, J. Phys. Chem. A, 104, 819-829, 2000.

Usher, C. R., Michel, A. E., and Grassian, V. H.: Reactions on mineral dust, Chem. Rev., 103, 4883-4939, 2003a.

Usher, C. R., Michel, A. E., Stec, D., and Grassian, V. H.: Laboratory studies of ozone uptake on processed mineral dust, Atmos. Environ., 37, 5337-5347, 2003b.
Watts, S. F.: The mass budgets of carbonyl sulfide, dimethyl sulfide, carbon disulfide and hydrogen sulfide, Atmos. Environ., 34, 761$779,2000$.

Wu, H. B., Wang, X., Cheng, J. M., Yu, H. K., Xue, H. X., Pan, X. X., and Hou, H. Q.: Mechanism of the heterogeneous reaction of carbonyl sulfide with typical components of atmospheric aerosol, Chinese Sci. Bull., 49, 1231-1235, 2004.

Wu, H. B., Wang, X., and Cheng, J. M.: Photooxidation of carbonyl sulfide in the presence of the typical oxides in atmospheric aerosol, Sci. China. Ser. B, 48, 31-37, 2005. 